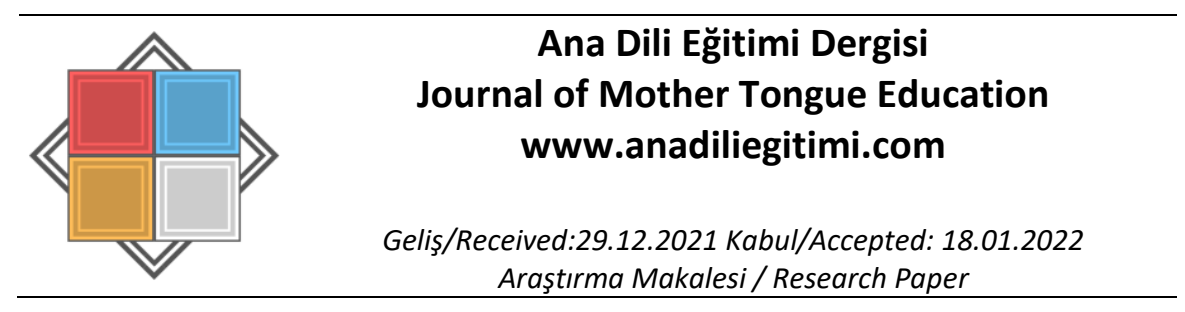

\title{
Türkçe Eğitimi Öğretim Elemanlarının Teknoloji Yeterliliklerine Yönelik Görüşleri
}

\author{
Osman Kürşat YORGANCI*
}

Öz

Bu araştırmanın amacı, Türkçe eğitimi öğretim elemanlarının teknoloji yeterliliklerine dair görüşlerini belirlemektir. Öğretim elemanlarının görüşleri araştırmacı tarafından oluşturulan "Öğretmen Eğiticileri Teknoloji Yeterlilikleri Anketi" ile Google Formlar üzerinden alınmıştır. Anket, kişisel bilgilerle soruların yer aldığı iki ayrı bölümden oluşmaktadır. Çalışma nicel araştırma yöntemlerinden tarama deseniyle yürütülmüştür. Çalışma verileri 38 farklı üniversitenin 88 Türkçe eğitimi öğretim elemanından alınan görüşlerden elde edilmiştir. Veriler betimsel analiz tekniği kullanılarak analiz edilmiştir. Yeterliliklerin varlı̆̆ı, yokluğu veya kısmen varlığı anlamına gelen "evet", "hayır" ve "kısmen" yanıtları sayısal ifadelere dönüştürülerek frekans ve yüzdeler ile sunulmuş ve değerlendirilmiştir. Türkçe eğitimi öğretim elemanlarının 12 ana, 41 alt maddeden oluşan anketin "5.1. Farkı öğrencilerin intiyaçlarını karşılayabilmek için teknoloji kullanarak öğretim tasarlarım.", "6.2. Çeşitli teknolojik değerlendirme uygulamaları kullanarak öğretmen adaylarına model olurum.", "8.1. Öğretmen adaylarına teknoloji kullanarak diğer kültür ve bölgelerle iletişime geçip küresel bağlantılar kurması için model olurum.", "10.2. Teknoloji bilgi ve becerilerimi destekleyen sürekli mesleki gelişim ve iletişim faaliyetlerine katılırım.", "11.2. Eğitimde teknoloji kullanımını savunan profesyonel kuruluşlarla etkileşim kurarım." ve "11.3. Teknoloji entegrasyonuyla ilgili olarak öğretmen adaylarının düşünce ve kararlarını etkilerim." maddelerinde kısmen yeterli; "8.2. Öğretmen adaylarının farklı kültürlere ve deneyimlere sahip öğrencilerle teknoloji kullanarak iş birliği yapabilecekleri öğretim içerikleri tasarlarım." ve "8.3. Farklı düzeylerde teknolojik bağlantı ağına sahip bölge ve kültürler için öğretmen adaylarının intiyaç duyabilecekleri stratejileri ele alıım." maddelerinde yetersiz; diğer maddelerde ise yeterli olduklarını düşündükleri sonucuna ulaşılmış, elde edilen sonuçlardan hareketle çeşitli önerilerde bulunulmuştur.

Anahtar Kelimeler: Türkçe eğitimi, öğretim elemanları, teknoloji, teknoloji yeterlilikleri

\section{The Views of Turkish Education Lecturers on Technological Competencies}

\begin{abstract}
The aim of this research is to determine the views of Turkish education lecturers on technology competencies. The opinions of the lecturers were gotten on Google Forms through "Teacher Trainers Technology Competencies Questionnaire" created by the researcher. The questionnaire consists of two separate parts which are personal information and questions. The study was carried out via a survey design which is one of the quantitative research methods. The study data was collected from the opinions of 88 Turkish education instructors from 38 different universities. The data was analyzed by using the descriptive analysis technique. The answers "yes", "no" and "partially", which mean the presence, absence or partial presence of qualifications, were presented and evaluated with frequencies and percentages by converting them into numerical expressions. It has been found out that Turkish education lecturers thought that they were partly sufficient in the items "5.1. I design instruction using technology to meet the needs of different students.", "6.2. I become a model for teacher candidates by using various technological evaluation applications.", "8.1. I become a model for teacher candidates to
\end{abstract}

\footnotetext{
* Öğr. Gör. Dr., Yıldız Teknik Üniversitesi, Rektörlük, TÖMER, i̇stanbul, yorganci@yildiz.edu.tr, OCRiD: ocrid.org/0000-0001-8230-219X
} 
communicate with other cultures and regions and establish global connections by using technology.", "10.2. I participate in continuous professional development and communication activities that support my technology knowledge and skills.", "11.2. I interact with professional organizations that advocate the use of technology in education." and "11.3. I influence the thoughts and decisions of teacher candidates regarding technology integration."; and insufficient in the items "8.2. I design instructional content in which prospective teachers can collaborate with students from different cultures and experiences using technology." and "8.3. I discuss strategies that prospective teachers may need for regions and cultures with different levels of technological connectivity." and sufficient in the other items of the questionnaire which consists of 12 main and 41 sub-items and thus different suggestions were proposed based on the obtained results.

Keywords: Turkish education, lecturers, technology, technological competencies

\section{Giriş}

Teknolojinin çok hızlı geliştiği çağımızda; bireylerin, dolayısıyla da toplumun bu gelişmelere uyum sağlayarak ilerlemesi gerekmektedir. Yeni teknolojiler yaşamın hemen her alanına girerek yaşamsal faaliyetlerin tamamını önemli derecede etkilemektedir. Hemen her yaşam alanı gibi eğitim de değişen ve gelişen bu yeni teknolojilerden etkilenmektedir. Teknolojideki değişim ve gelişimin doğal bir sonucu olarak çağın intiyaçlarını karşılayabilecek bilgi, beceri ve davranışlara sahip bireylerin yetiştirileceği eğitim ortamlarına teknolojinin dâhil edilmesi her geçen gün daha büyük bir önem göstermektedir.

21. yüzyıl teknolojisinin son değişikliklerinden ve geliş̧melerinden etkilenen en önemli alanlardan birinin eğitim olduğu düşünüldüğünde çağa ayak uydurabilecek özelliklere sahip nitelikli bireylerin yetiştirilmesinin ancak etkili bir eğitimle sağlanabileceği; bireylerde istendik davranışlar meydana getirebilecek etkili bir eğitimin olmazsa olmazının ise eğitim programları olduğu bilinmektedir. Çünkü eğitim kurumlarının bireylerin yaşantılarını düzenlemek için gerçekleştirdikleri faaliyetlerin tamamı eğitim programı kavramı içerisinde değerlendirilmektedir. Dijital yerliler olarak isimlendirilen çağımız öğrencileri günlerinin önemli bir bölümünü akıllı cep telefonu, bilgisayar veya tabletler ile internette geçirmekte; türlü bilgiye ulaşmak için akıllı telefon ya da bilgisayarlara başvurmakta; grup görevlerinden hoşlanmakta; sosyal etkileşim yoluyla yeni bilgiler edinmekte ve genellikle görsel öğeleri metinlere tercih etmektedirler. Bu sebeple neredeyse bütün dünyada çokça kullanılan bu teknolojilerin, bilgi ve iletişim teknolojilerinin, eğitim-öğretim programlarına aktarılıp öğrenme-öğretme süreçlerine dâhil edilmesi gerekmektedir (Çam, 2018).

Çağın gereği yeniliklere açık ve teknolojiye uyum sağlayabilen 21. yüzyıl becerilerine sahip dijital yerliler olarak isimlendirilen öğrenciler kadar öğretmenlerin de bilgi ve iletişim teknolojilerinden öğrenme-öğretme sürecinde etkili bir şekilde yararlanabilecek bilgi ve becerilere sahip olmaları beklenmektedir. Eğitim programlarının eğitim-öğretim sürecindeki uygulayıcıları olan öğretmenlerin dijital yerlilerin karşısında dijital yabancılar olmamaları gerekmektedir. Çünkü 21. yüzyıl öğretmenlerinden öğrenme-öğretme süreçlerinde derslerinin hedeflerine uygun teknolojileri seçebilmeleri, bunları derslerinde kullanabilmeleri ve kendilerini sürekli geliştirmeleri beklenmektedir.

Bir milletin ve toplumun geleceğini öğretmenler biçimlendirmektedir. Gelecek nesiller günümüz öğretmenleri eliyle şekillendirilecektir. Nitelikli öğrenciler yetiştirebilmek için öncelikle öğretmenlerin kendilerini daha donanımlı hâle getirmeleri gerekmektedir. Teknolojinin hayatın hemen her alanında kullanımının adeta bir zorunluluk hâline geldiği günümüzde teknolojiyi eğitime dâhil ederek eğitimle bütünleştirmek kaçınılmaz görünmektedir. Eğitim ve eğitimde teknoloji kullanımı günümüz dünyasının vazgeçilemez iki kavramı olarak değerlendirilmektedir. Teknoloji kullanımının eğitim için önemi tartışılamaz bir gerçek olarak karşımıza çıkmaktadır. Eğitimde teknolojiyi etkili ve verimli kullanabilmek için öğretmenlerin kendi uzmanlık alanlarıyla teknolojiyi birleştirmeleri gerekmektedir. Bu sebeple eğitimcilerin derslerinde kullanabilecekleri her türlü teknolojik bilgiyi kazanabilecek ve teknolojik gelişmeler ışı̆̆ında eğitim-öğretim durumlarını yeniden gözden geçirebilecek yeterliliklere sahip olmaları gerekmektedir (Yarar, 2019). 
Bazı araştırmalar öğretmenlerin önemli bir kısmının öğrenme-öğretme sürecinde teknolojiyi sadece veri saklama, internetten kaynak bulma ve PowerPoint ile sunum hazırlama gibi algıladığını ortaya koymaktadır. Bu araştırmalarda öğretmenlerin teknoloji kullanımında kendilerini endişeli hissettikleri, değişime uyum sağlayamadıkları, yeterli destek olmadığından teknolojideki yenilikleri benimseyemedikleri ve yaşları ilerledikçe teknoloji kullanımına dönük olumsuz tutum geliştirdikleri belirtilmektedir. Ayrıca yine bu araştırmalarda teknolojinin giderek artan bir ihtiyaca dönüşmesinin doğal bir sonucu olarak öğretmen yetiştiren kurumların programlarında bu ihtiyacı karşılayacak düzenlemelerin yapılmaya başlandığının ve yapılmaya devam edilmesi gerektiğinin, bu bağlamda teknoloji entegrasyonunun gerçekleştirilebilmesi için öğretim elemanlarının öğretmen adaylarına sahip olmaları gereken bilgi ve becerileri kazandırmak üzere eğitim vermeleri gerektiğinin, bunun için de her şeyden önce yeni teknolojilerin eğitime entegrasyonunu sağlayabilmek adına akademisyenlerin teknolojiyi etkili bir şekilde kullanabilme yeterliliklerinin geliştirilmesinin oldukça önemli olduğuna vurgu yapılmaktadır (Aksu, Çivitçi, ve Duy, 2008; Odabaşı ve diğ., 2010; Turan, Küçük ve Gündoğdu 2013; Başıbüyük, 2015; Kabaran, 2016; YÖK, 2018; Çakan, 2021).

Öğretim elemanlarından geleneksel rollerinin yanında günümüzde öğrencilere Teknoloji ile Zenginleştirilmiş Öğrenme (TZÖ) ortamları sunabilen rehberler olmaları da beklenmektedir. Öğretim elemanlarının eğitim sürecinde farklı öğrenme kuramlarından yararlanarak TZÖ tasarlayabilmeleri, geliştirebilmeleri ve kullanabilmeleri istenmektedir. Öğretim elemanlarının kendilerinden beklenen ve istenenleri gerçekleştirebilmeleri her şeyden önce sahip oldukları teknoloji bilgilerini geliştirmeleri ve bu bağlamda yeterlilik sahibi olmalarını gerekmektedir. Değişen akademisyen rolü gereği öğretim elemanlarının sadece bilgi teknolojileri okuryazarları olmalarının artık yetmeyeceği, derslerine ve alanlarına uygun endüstri intiyaçlarına göre TZÖ ortamlarını eğitim programlarıyla bütünleştirmeleri gerektiği vurgulanmaktadır (Elçi ve Vural, 2018).

Günümüzde yeni teknolojilerin eğitime entegrasyonu için öğretim elemanlarının alan uzmanı olarak sahip oldukları bilgileri öğrencilere aktarmalarııı ötesinde sahip olmaları gereken yeni yeterliliklerin altı çizilmektedir. Öğretim elemanlarının alan, pedagoji ve teknoloji bilgileri konusundaki yeterlilikleri Teknolojik Pedagojik Alan Bilgisi (TPAB) olarak açıklanmaktadır. Bu sebeple $T P A B$, günümüzde öğretim elemanlarının mevcut alan ve pedagoji bilgileriyle yeni teknoloji bilgilerini bütünleştirebilme becerileri anlamına gelen önemli bir nitelik olarak karşımıza çıkmaktadır (Kabaran ve Aykaç, 2018).

Eğitimcilerin sahip olmaları gereken alan bilgileriyle bu bilgilerin etkili bir biçimde öğrenene aktarılmasını sağlayan pedagojik bilgiye günümüz intiyaçları doğrultusunda teknoloji bilgisinin de eklenmesi sonucu ortaya çıkan TPAB, Pierson (1999)'a göre "eğitimcilerin teknolojiyi ve teknolojik araçları dersin amaçları doğrultusunda etkili ve verimli bir biçimde kullanabilmesi" şeklinde açıklanmaktadır (Yarar, 2019).

Akademisyenlerin TPAB seviyeleri; onların uzmanlık alanlarıyla ilgili donanımları, eğitimöğretim sürecinde tercih ettikleri yöntem ve teknikler, teknolojiden faydalanma düzeyleri ve bunların tamamını bir araya getirebilme yeterlilikleri anlamına gelmektedir. Öğretim elemanlarının sahip oldukları teknolojik yeterliliklerin ne seviyede olduğunun belirlenmesi yükseköğretim kurumları için önem taşımaktadır. Alan yazın tarandığında teknoloji yeterlilikleriyle ilgili çalışmaların genelinin öğretmen, öğretmen adayı ve öğrencilerle gerçekleştirildiği; öğretim elemanlarının teknoloji yeterliliklerine dair sınırlı sayıda çalışma yapıldığı görülmektedir (Kabaran ve Aykaç, 2018; Güntepe ve Keleş, 2018; Çakır ve Önal, 2015). Türkçe eğitimi öğretim elemanlarının teknoloji yeterliliklerini ele alan araştırmalar arasında ilklerden olacak bu çalışmanın literatüre katkı sağlayacağı ve bu bağlamda yapılacak yeni çalışmalara ışık tutacağı düşünülmektedir. 


\section{Yöntem}

Bu bölümde çalışmanın modeli, örneklemi, veri toplama aracı, verilerinin toplanması ve analiz süreçleri ile araştırma yayın etiği ve etik kurul izni bilgileri ele alınmaktadır.

\section{Araştırmanın Modeli}

Bu çalışma, nicel araştırma yöntemlerinden tarama deseniyle gerçekleştirilmiştir. Creswell (2017)'e göre bu desenle bir evren içinden seçilen bir örneklem üzerinde yapılan çalışmalar sayesinde evren genelindeki eğilim, tutum veya görüşler nicel veya nümerik olarak betimlenebilir. Başka bir deyişle bir grubun belirli özelliklerini belirlemek için verilerin toplanmasını amaçlayan çalışmalara tarama araştırması denilmektedir (Büyüköztürk ve diğerleri, 2013).

\section{Örneklem}

Çalışmanın örneklemini 2021-2022 eğitim-öğretim yılında özel (vakıf) üniversiteler ile devlet üniversitelerinin Türkçe eğitimi anabilim dallarında ders veren öğretim elemanları oluşturmaktadır. Çalışma örnekleminde 38 üniversiteden 88 öğretim elemanı yer almaktadır. Üniversitelerden 4'ü özel, 34 'ü devlet üniversitesi; öğretim elemanlarından $8^{\prime} i$ özel üniversite, $80^{\prime} i$ ise devlet üniversitesi öğretim elemanıdır. Örneklemi oluşturan üniversiteler ile öğretim elemanı sayılarını gösterir tablo aşağıdaki gibidir:

\begin{tabular}{|l|l|}
\hline Üniversiteler & Öğretim Elemanı Sayısı \\
\hline Adıyaman Üniversitesi & 2 \\
\hline Akdeniz Üniversitesi & 1 \\
\hline Alanya Alaaddin Keykubat Üniversitesi & 3 \\
\hline Amasya Üniversitesi & 2 \\
\hline Aydın Adnan Menderes Üniversitesi & 1 \\
\hline Bartın Üniversitesi & 3 \\
\hline Bayburt Üniversitesi & 2 \\
\hline Bursa Uludağ Üniversitesi & 7 \\
\hline Çanakkale Onsekiz Mart Üniversitesi & 4 \\
\hline Düzce Üniversitesi & 3 \\
\hline Erciyes Üniversitesi & 2 \\
\hline Eskişehir Osmangazi Üniversitesi & 1 \\
\hline Fatih Sultan Mehmet Vakıf Üniversitesi & 2 \\
\hline Gazi Üniversitesi & 4 \\
\hline Hacettepe Üniversitesi & 3 \\
\hline Hatay Mustafa Kemal Üniversitesi & 1 \\
\hline İstanbul Aydın Üniversitesi & 3 \\
\hline İstanbul Medeniyet Üniversitesi & 3 \\
\hline İstanbul 29 Mayı Üniversitesi & 2 \\
\hline İstanbul Sebahattin Zaim Üniversitesi & 2 \\
\hline Kastamonu Üniversitesi & 2 \\
\hline Kocaeli Üniversitesi & 1 \\
\hline Kütahya Dumlupınar Üniversitesi & 1 \\
\hline Malatya İnönü Üniversitesi & 2 \\
\hline Marmara Üniversitesi & 2 \\
\hline Muğla Sıtkı Koçman Üniversitesi & 2 \\
\hline Muş Alparslan Üniversitesi & 2 \\
\hline Necmettin Erbakan Üniversitesi & 1 \\
\hline Nevşehir Hacı Bektaş Veli Üniversitesi & 2 \\
\hline Ordu Üniversitesi & 1 \\
\hline
\end{tabular}




\begin{tabular}{|l|l|}
\hline Pamukkale Üniversitesi & 2 \\
\hline Recep Tayyip Erdoğan Üniversitesi & 6 \\
\hline Sakarya Üniversitesi & 3 \\
\hline Trabzon Üniversitesi & 1 \\
\hline Uşak Üniversitesi & 1 \\
\hline Yıldız Teknik üniversitesi & 4 \\
\hline Yozgat Bozok Üniversitesi & 1 \\
\hline Zonguldak Bülent Ecevit Üniversitesi & 3 \\
\hline Toplam & Toplam \\
\hline 38 & 88 \\
\hline
\end{tabular}

\section{Veri Toplama Aracı}

Çalışmada veri toplama aracı olarak ABD Eğitim Bakanlığı Eğitim Teknolojileri Ofisi'nin ABD Ulusal Eğitim Teknolojisi Planı (U.S. Department of Education, 2017) çerçevesinde öğretmen adaylarını teknolojiyle öğretmeye hazırlayan öğretmen eğiticileri için ortak bir teknoloji yeterlilikleri seti oluşturma çağrısı üzerine Foulger ve diğerleri (2017) tarafından hazırlanan yeterlilikler listesinden hareketle araştırmacı tarafından oluşturulan "Öğretmen Eğiticileri Teknoloji Yeterlilikleri Anketi" kullanılmıştır.

12 ana madde ve 41 alt maddeden oluşan anketin kapsam geçerliliğini sağlamak üzere 5 Türkçe eğitimi, 2 eğitim bilimleri, 2 ölçme ve 1 yabancı dil uzamanı olmak üzere 10 öğretim elemanından görüş alınmıştır.

\section{Verilerin Toplanması ve Analizi}

Türkçe eğitimi öğretim elemanlarının teknoloji yeterliliklerine dair görüşleri 01.12.2021 ila 15.12.2021 tarihleri arasında, araştırmacı tarafından oluşturulan "Öğretmen Eğiticilerinin Teknoloji Yeterlilikleri Anketi" ile Google Formlar üzerinden toplanmıştır.

Çalışma verileri betimsel teknikle analiz edilmiş, elde edilen sayısal değerler frekans ve yüzde analizleri ile sunulmuştur.

\section{Araştırma ve Yayın Etiği}

Çalışmada "Yükseköğretim Kurumları Bilimsel Araştırma ve Yayın Etiği Yönergesi"nde uyulması gereken kurallar olarak ifade edilenlerin tamamına riayet edilmiştir. Illgili yönergenin "Bilimsel Araştırma ve Yayın Etiğine Aykırı Eylemler" başıkıı ikinci bölümünde belirtilen eylemlerden hiçbiri gerçekleşmemiştir.

\section{Etik Kurul izni}

Kurul adı = Yıldız Teknik Üniversitesi Sosyal ve Beşeri Bilimler Araştırmaları Etik Kurulu Etik Kurulu Karar tarihi $=20.10 .2021$

Toplantı No= 2021/08 


\section{Bulgular}

Çalışmanın bu bölümünde öğretim elemanlarına uygulanan "Öğretmen Eğiticileri Teknoloji Yeterlilikleri Anketi" sonucunda ulaşılan bulgular grafikler şeklinde açıklama ve yorumlarıyla birlikte ele alınmaktadır.

Mesleki deneyim yııınıza uygun olan seçeneği işaretleyiniz.

88 yanit

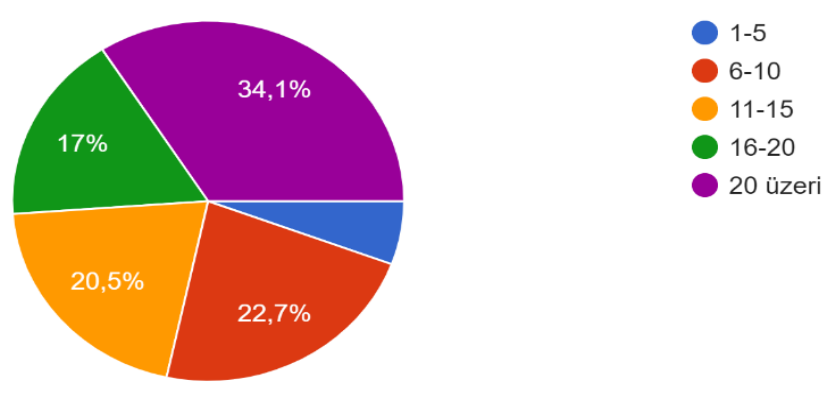

Grafik 1.

Lisansüstü eğitimde öğrenci olduğunuz dönemlerde teknolojiyle ilgili ders alma durumunuza uygun olan seçeneği işaretleyiniz.

88 yanit

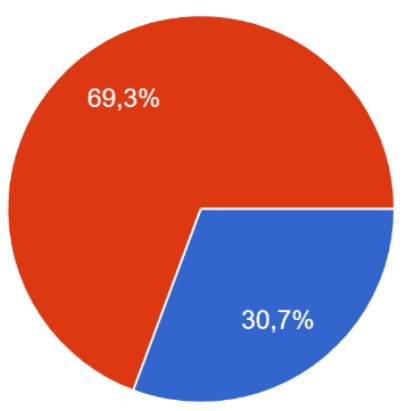

Teknoloji ile ilgili ders aldım.

Teknoloji ile ilgili ders almadım.

Grafik 2.

İki bölümden oluşan “Öğretmen Eğiticileri Teknoloji Yeterlilikleri Anketi”nin ilk bölümü olan "Kişisel Bilgi Formu" ile çalışmaya katılan 88 Türkçe eğitimi öğretim elemanından elde edilen mesleki deneyim, lisansüstünde teknoloji dersi alma durumu ve meslek yaşamında yüz yüze veya çevrim içi teknoloji çalışmalarına katılım durumu bilgileri; içerisinde bulunduğumuz yüzyıl, bu yüzyılın teknoloji anlayışı, eğitimde teknoloji kullanımı, öğrenenlerin teknoloji ihtiyaçları ve öğretenlerin teknoloji yeterlilikleriyle ilgisi olması bakımından dikkat çekmektedir.

Grafik 1'de çalışmaya katılan 88 öğretim elemanından 5'inin 1 ila 5, 20'sinin 6 ila 10, 18'inin 11 ila 15,15 'inin 16 ila 20 ve 30'unun 20 ve üzeri yıllık tecrübeye sahip olduğu görülmektedir.

Grafik 2'de 88 öğretim elemanından 61'inin lisansüstü öğrencilik dönemlerinde teknolojiyle ilgili ders almadığı, 27'sinin ders aldığı anlaşılmaktadır. 
Meslek yaşamınızda teknolojiyle ilgili yüz yüze veya çevrim içi atölye çalışması, çalıştay vb. çalışmalara katııım durumunuza uygun olan seçeneği işaretleyiniz. 88 yanit

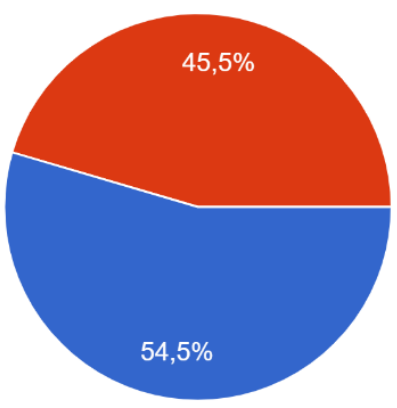

İlgili çalışmalara katıldım.

İlgili çalışmalara katılmadım.

\section{Grafik 3.}

Grafik 3'te 88 öğretim elamanından 40'ının meslek yaşamında teknolojiyle ilgili çalışmalara katılmadığı, 48'inin ise katıldığı görülmektedir.

Grafik 1, Grafik 2 ve Grafik 3 birlikte ve dikkatli incelenip yorumlandığında teknolojik yerliler şeklinde isimlendirilen günümüz öğrencilerinin eğitimlerini üstlenen öğretim elemanlarının önemli bir kısmının lisansüstü dönemlerinde teknolojiyle ilgili ders almadığı, yine önemli bir kısmının da meslek yaşamlarında teknolojiyle ilgili çalışmalara katılmadığı görülmektedir. Bu durum mesleki deneyim yıllarını gösteren bilgilerden de anlaşılabileceği üzere öğretim elemanlarının lisansüstü eğitim dönemlerinden bugüne uzun bir zaman geçmesiyle açıklanabilir olmakla beraber yükseköğretimde günümüz teknoloji intiyaçlarının karşılanabilmesi adına da bir soru işareti olarak karşımıza çıkmaktadır.

"Kişisel Bilgiler Formu"ndan elde edilen bilgilerin gösterilip yorumlanmasının ardından 88 öğretim elemanının 12 ana, 41 alt maddeden oluşan "Öğretmen Eğiticileri Teknoloji Yeterlilikleri Anketi"ne vermiş oldukları cevapları gösteren grafiklere ilişkin bulgu ve yorumlara aşağıda yer verilmiştir.

Öğrenme ve öğretmeyi geliştirmek için içeriğe özgü teknolojiler barındıran öğretim tasarlayabilme:

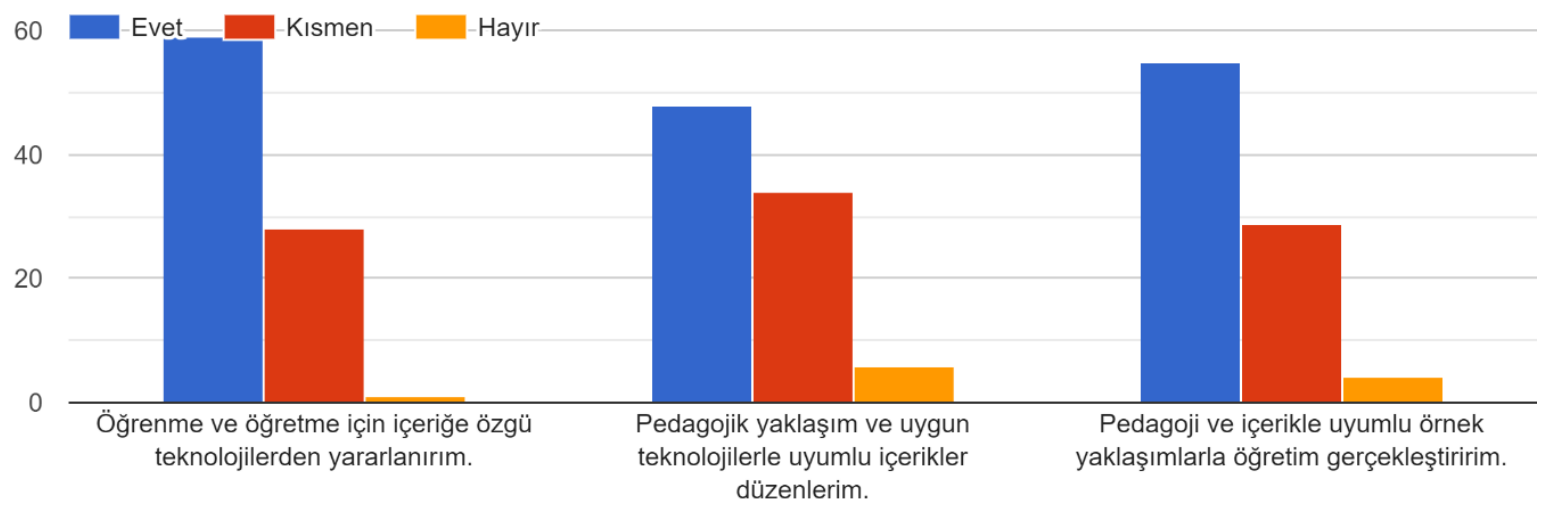

Grafik 4. 
Öğretim elemanları "1. Öğrenme ve öğretmeyi geliştirmek için içeriğe özgü teknolojiler barındıran öğretim tasarlayabilme:" başlıklı 3 alt maddeden oluşan sorulara genel olarak kendilerini yeterli gördükleri cevabını vermişlerdir.

"1.1. Öğrenme ve öğretme için içeriğe özgü teknolojilerden yararlanırım." sorusuna 88 öğretim elemanından $59^{\prime}$ unun yeterliyim, $28^{\prime}$ inin kısmen yeterliyim ve $1^{\prime}$ inin yetersizim cevabını verdiği görülmektedir.

"1.2. Pedagojik yaklaşım ve uygun teknolojilerle uyumlu içerikler düzenlerim." sorusuna 88 öğretim elemanından 48'inin yeterliyim, 34'ünün kısmen yeterliyim ve 6'sının yetersizim cevabını verdiği görülmektedir.

"1.3. Pedagoji ve içerikle uyumlu örnek yaklaşımlarla öğretim gerçekleştiririm." sorusuna 88 öğretim elemanından $55^{\prime}$ inin yeterliyim, 29 'unun kısmen yeterliyim ve 4 'ünün yetersizim cevabını verdiği görülmektedir.

Öğretmen adaylarını teknolojiyi etkili bir şekilde kullanmaya hazırlayacak pedagojik yaklaşımları eğitimlerine dâhil edebilme:

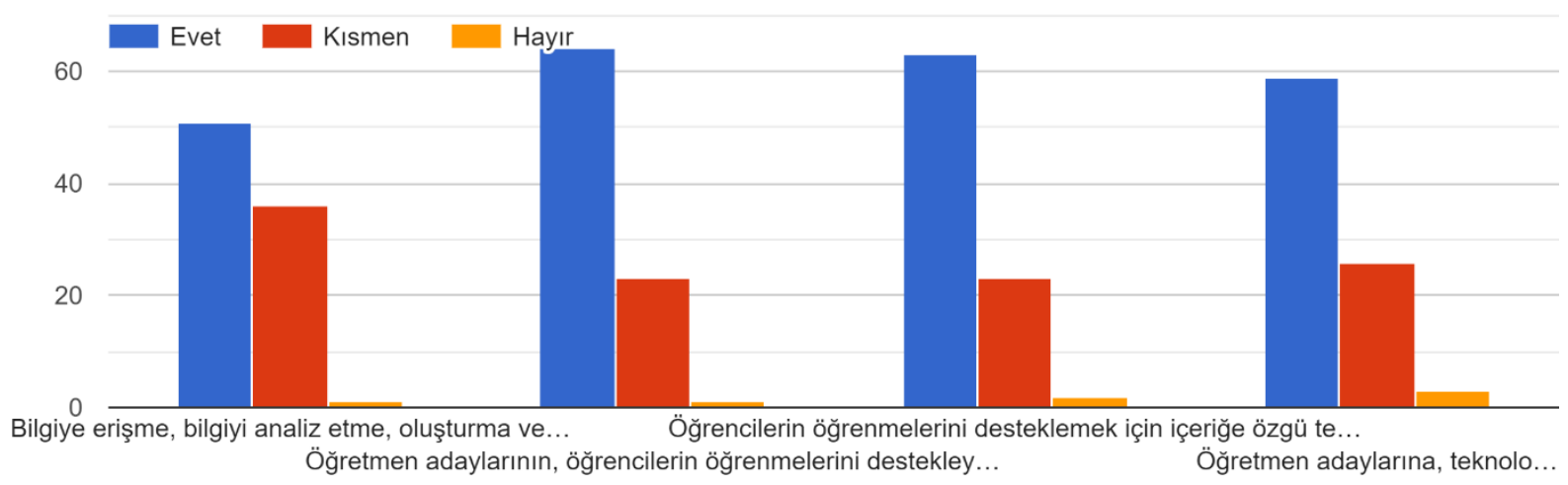

Grafik 5.

Öğretim elemanları "2. Öğretmen adaylarını teknolojiyi etkili bir şekilde kullanmaya hazırlayacak pedagojik yaklaşımları eğitimlerine dâhil edebilme:" başlıklı 4 alt maddeden oluşan sorulara genel olarak kendilerini yeterli gördükleri cevabını vermektedirler:

"2.1. Bilgiye erişme, bilgiyi analiz etme, oluşturma ve değerlendirme için teknoloji kullanımına model olurum." sorusuna 88 öğretim elemanından 51'i yeterliyim, 36'sı kısmen yeterliyim ve $1^{\prime} i$ yetersizim cevabını vermiştir.

"2.2. Öğretmen adaylarının, öğrencilerin öğrenmelerini destekleyebilecekleri içeriğe özgü teknoloji olanaklarından yararlanmalarını sağlarım." sorusuna 88 öğretim elemanından 64'ünün yeterliyim, 23'ünün kısmen yeterliyim ve 1'inin yetersizim cevabını verdiği görülmektedir.

"2.3. Öğrencilerin öğrenmelerini desteklemek için içeriğe özgü teknolojilerin seçimi ve kullanımı konusunda öğretmen adaylarına yardımcı olurum." sorusuna 88 öğretim elemanından 63'ünün yeterliyim, 23'ünün kısmen yeterliyim ve 2'sinin yetersizim cevabını verdiği görülmektedir.

"2.4. Öğretmen adaylarına, teknolojiyle öğretim için uygulama fırsatları sağlarım." sorusuna 88 öğretim elemanından $59^{\prime}$ unun yeterliyim, 26 'sının kısmen yeterliyim ve 3'ünün yetersizim cevabını verdiği görülmektedir. 
Öğretmen adaylarının teknolojik alan bilgi, beceri ve tutumlarının gelişimini destekleyebilme:

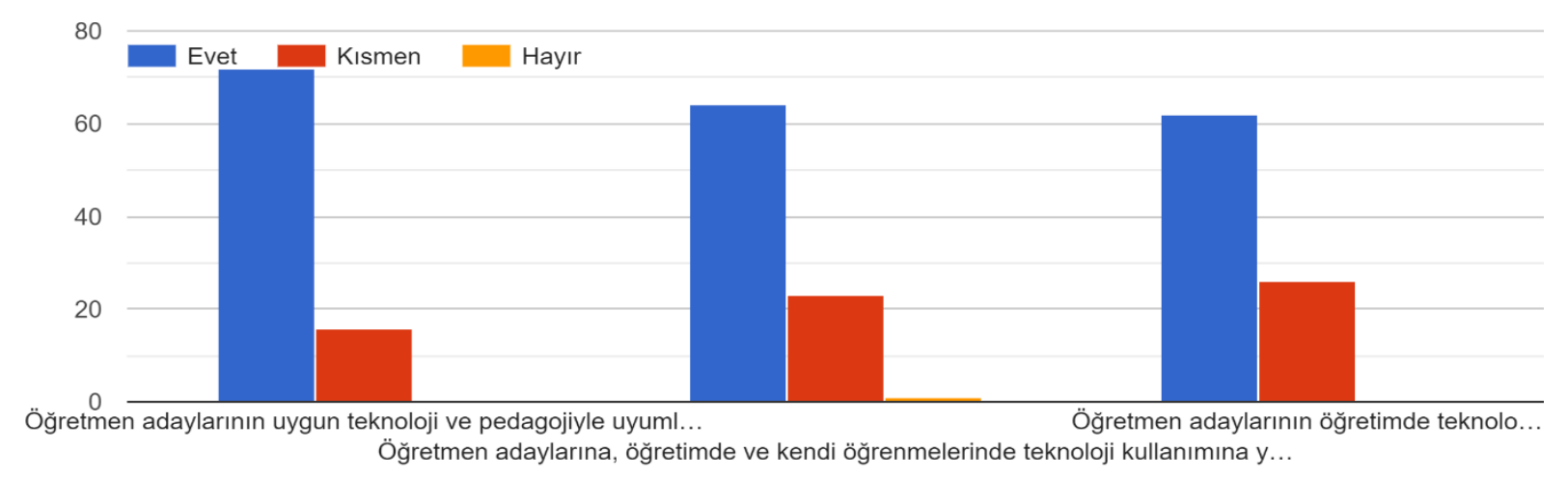

Grafik 6.

Öğretim elemanları "3. Öğretmen adaylarının teknolojik alan bilgi, beceri ve tutumlarının gelişimini destekleyebilme:" başlıklı 3 alt maddeden oluşan sorulara genel olarak kendilerini yeterli gördükleri cevabını vermektedirler:

"3.1. Öğretmen adaylarının uygun teknoloji ve pedagojiyle uyumlu içerik oluşturmalarını desteklerim." sorusuna 88 öğretim elemanından 72 'sinin yeterliyim, 16'sının ise kısmen yeterliyim cevabını verdiği görülmektedir.

“3.2. Öğretmen adaylarına, öğretimde ve kendi öğrenmelerinde teknoloji kullanımına yönelik tutumlarını yansıtma fırsatları sunarım." sorusuna 88 öğretim elemanından 64'ünün yeterliyim, 23 'ünün kısmen yeterliyim ve 1 'inin yetersizim cevabını verdiği görülmektedir.

"3.3. Öğretmen adaylarının öğretimde teknoloji kullanımı konusundaki yeterliliklerini geliştirmelerine olanak sağlarım." sorusuna 88 öğretim elemanından 62 'sinin yeterliyim, 26'sının ise kısmen yeterliyim cevabını verdiği görülmektedir.

Öğrenme ve öğretmeyi geliştirmek için çevrim içi araçları kullanabilme:

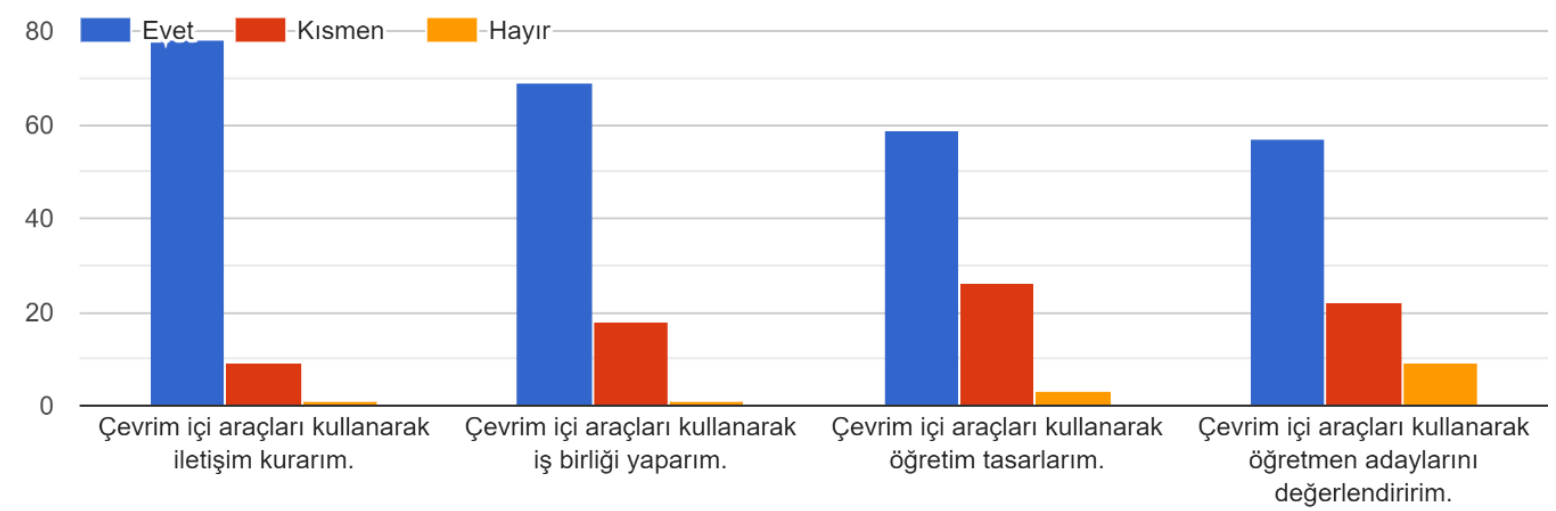

Grafik 7.

Öğretim elemanları "4. Öğrenme ve öğretmeyi geliştirmek için çevrim içi araçları kullanabilme:" başlıklı 4 alt maddeden oluşan sorulara genel olarak kendilerini yeterli gördükleri cevabını vermektedirler: 
"4.1. Çevrim içi araçları kullanarak iletişim kurarım." sorusuna 88 öğretim elemanından 78'inin yeterliyim, 9'unun kısmen yeterliyim ve 1'inin yetersizim cevabını verdiği görülmektedir.

"4.2. Çevrim içi araçları kullanarak iş birliği yaparım." sorusuna 88 öğretim elemanından 69 'unun yeterliyim, 18' inin kısmen yeterliyim ve 1 'inin yetersizim cevabını verdiği görülmektedir.

"4.3. Çevrim içi araçları kullanarak öğretim tasarlarım." sorusuna 88 öğretim elemanından 59 'unun yeterliyim, 26 'sının kısmen yeterliyim ve 3'ünün yetersizim cevabını verdiği görülmektedir.

"4.4. Çevrim içi araçları kullanarak öğretmen adaylarını değerlendiririm." sorusuna 88 öğretim elemanından 57 'sinin yeterliyim, 22 'sinin kısmen yeterliyim ve 9'unun yetersizim cevabını verdiği görülmektedir.

Farklı öğrenme ihtiyaçlarının karşılanması için öğretimi çeşitlendiren teknolojileri kullanabilme:

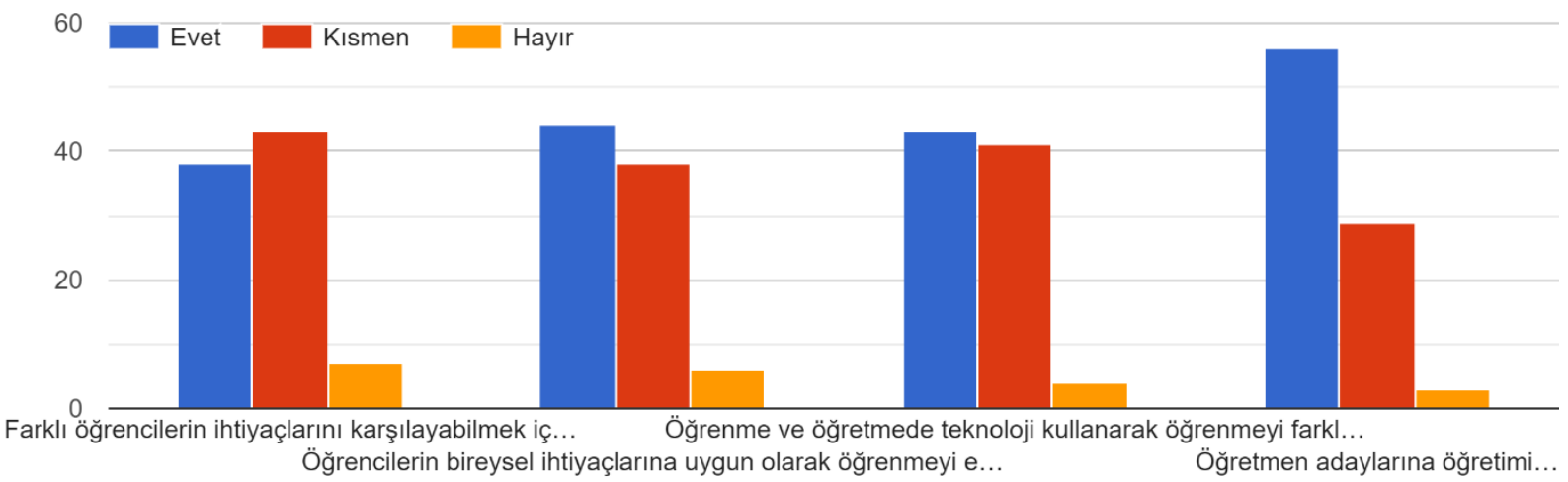

Grafik 8.

Öğretim elemanlarının "5. Farklı öğrenme ihtiyaçlarının karşılanması için öğretimi çeşitlendiren teknolojileri kullanabilme:" başlıklı 4 alt maddeden oluşan sorulara yeterlilik düzeylerini belirtmek üzere anket genelinden farklı cevaplar verdiği görülmektedir:

"5.1. Farklı öğrencilerin ihtiyaçlarını karşılayabilmek için teknoloji kullanarak öğretim tasarlarım." sorusuna 88 öğretim elemanından $38^{\prime}$ inin yeterliyim, 43'ünün kısmen yeterliyim ve 7'sinin yetersizim cevabını verdiği görülmektedir. Öğretim elemanlarının çoğunun maddeyle ilgili kendilerini kısmen yeterli gördüklerini belirtmeleri dikkat çekmektedir.

"5.2. Öğrencilerin bireysel ihtiyaçlarına uygun olarak öğrenmeyi en üst düzeye çıkarmak için kullanılabilecek yardımcı teknolojileri tanıtırım." sorusuna 88 öğretim elemanından 44'ünün yeterliyim, 38'inin kısmen yeterliyim ve 6'sının yetersizim cevabını verdiği görülmektedir.

“5.3. Öğrenme ve öğretmede teknoloji kullanarak öğrenmeyi farklılaştırmak için model olurum." sorusuna 88 öğretim elemanından 43'ünün yeterliyim, 41'inin kısmen yeterliyim ve 4'ünün yetersizim cevabını verdiği görülmektedir. Maddeyle ilgili olarak öğretim elemanlarının yeterliyim ve kısmen yeterliyim cevaplarının çok yakın olması dikkat çekmektedir.

"5.4. Öğretmen adaylarına öğretimi farklılaştırmak için teknoloji kullanarak öğrenme etkinlikleri oluşturma fırsatları sağlarım." sorusuna 88 öğretim elemanından 56'sının yeterliyim, 29'unun kısmen yeterliyim ve 3'ünün yetersizim cevabını verdiği görülmektedir. 
Değerlendirme için uygun teknoloji araçlarını kullanabilme:

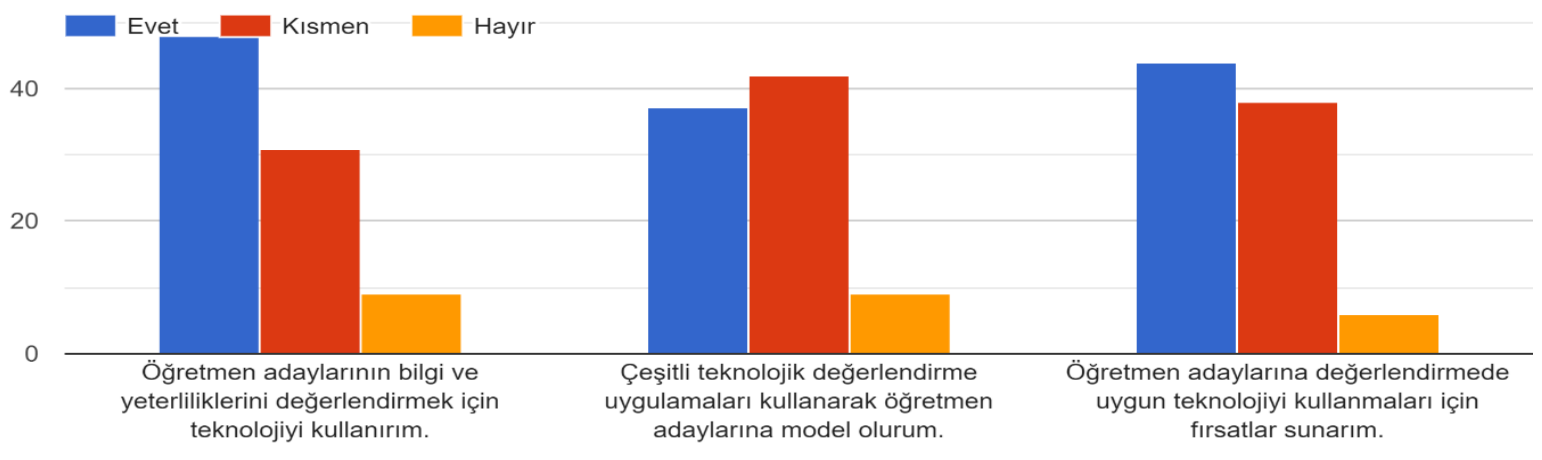

Grafik 9.

Öğretim elemanlarının "6. Değerlendirme için uygun teknoloji araçlarını kullanabilme:" başlıklı 3 alt maddeden oluşan bu sorulara da yeterlilik düzeylerini belirtmek üzere anket genelinden farklı cevaplar verdiği görülmektedir:

"6.1. Öğretmen adaylarının bilgi ve yeterliliklerini değerlendirmek için teknolojiyi kullanırım." sorusuna 88 öğretim elemanından 48'inin yeterliyim, 31'inin kısmen yeterliyim ve 9'unun yetersizim cevabını verdiği görülmektedir.

"6.2. Çeşitli teknolojik değerlendirme uygulamaları kullanarak öğretmen adaylarına model olurum." sorusuna 88 öğretim elemanından 37 'sinin yeterliyim, 42'sinin kısmen yeterliyim ve 9'unun yetersizim cevabını verdiği görülmektedir. Öğretim elemanlarının çoğunun maddeyle ilgili kendilerini kısmen yeterli gördüklerini belirtmeleri dikkat çekmektedir.

"6.3. Öğretmen adaylarına değerlendirmede uygun teknolojiyi kullanmaları için fırsatlar sunarım." sorusuna 88 öğretim elemanından 44'ünün yeterliyim, 38'inin kısmen yeterliyim ve 6'ünün yetersizim cevabını verdiği görülmektedir. Maddeyle ilgili olarak öğretim elemanlarının yeterliyim ve kısmen yeterliyim cevaplarının yakın olması dikkat çekmektedir.

Çevrim içi ve/veya harmanlanmış öğrenme ortamlarını öğretmek için etkili stratejiler kullanabilme:

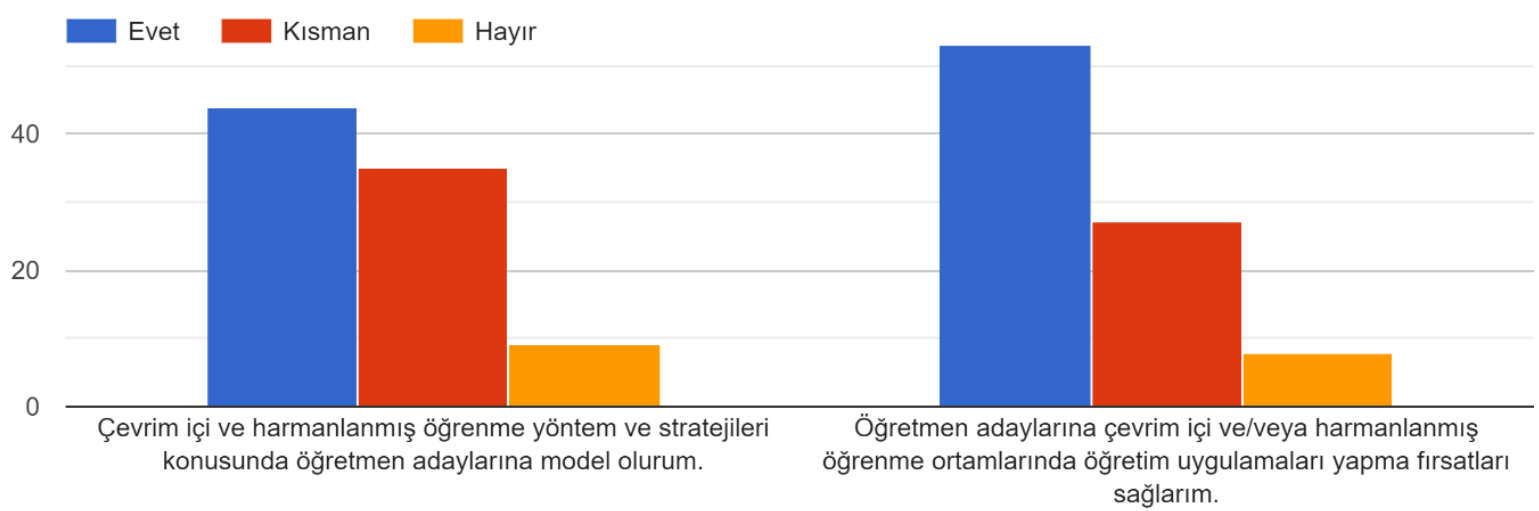

Grafik 10.

Öğretim elemanları "7. Çevrim içi ve/veya harmanlanmış öğrenme ortamlarını öğretmek için etkili stratejiler kullanabilme:" başlıklı 2 alt maddeden oluşan sorulara genel olarak kendilerini yeterli gördükleri cevabını vermektedirler: 
"7.1. Çevrim içi ve harmanlanmış öğrenme yöntem ve stratejileri konusunda öğretmen adaylarına model olurum." sorusuna 88 öğretim elemanından 44'ünün yeterliyim, 35'inin kısmen yeterliyim ve 9'unun yetersizim cevabını verdiği görülmektedir.

"7.2. Öğretmen adaylarına çevrim içi ve/veya harmanlanmış öğrenme ortamlarında öğretim uygulamaları yapma fırsatları sağlarım." sorusuna 88 öğretim elemanından 53'ünün yeterliyim, 27 'sinin kısmen yeterliyim ve 8 'inin yetersizim cevabını verdiği görülmektedir.

Çeşitli bölge ve kültürlerle küresel ölçekte iletişim kurmak için teknolojiyi kullanabilme:

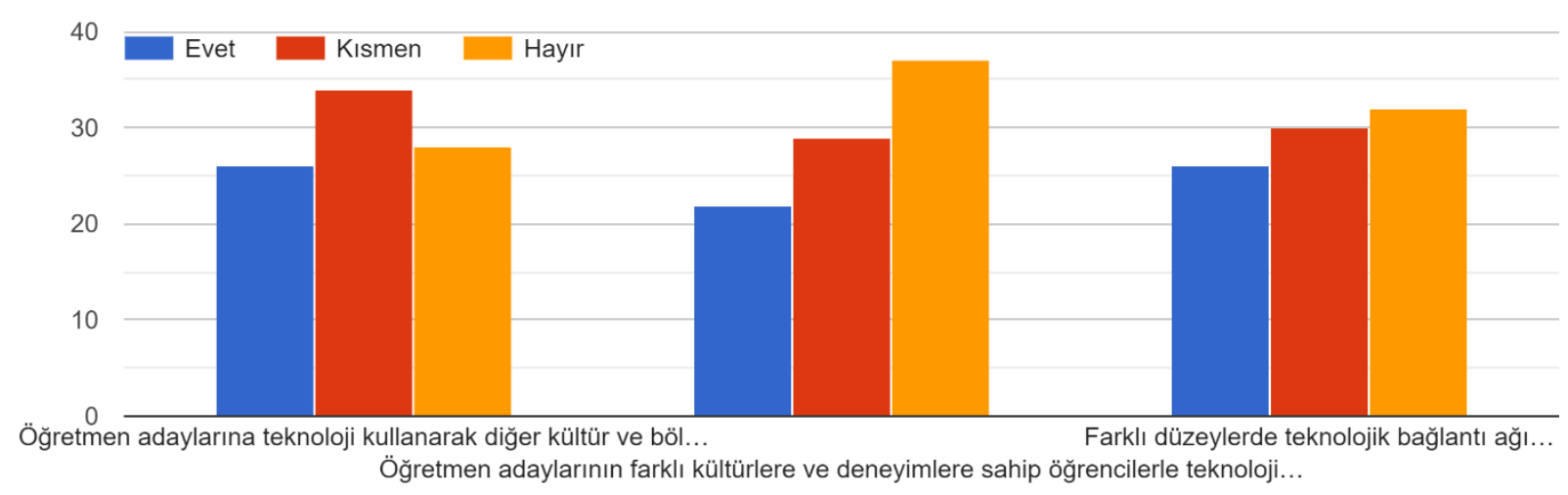

Grafik 11.

Öğretim elemanlarının "8. Çeşitli bölge ve kültürlerle küresel ölçekte iletişim kurmak için teknolojiyi kullanabilme:" başlıklı 3 alt maddeden oluşan sorulara yeterlilik düzeylerini belirtmek üzere anket genelinden daha farklı cevaplar verdiği dikkat çekmektedir:

"8.1. Öğretmen adaylarına teknoloji kullanarak diğer kültür ve bölgelerle iletişime geçip küresel bağlantılar kurması için model olurum." sorusuna 88 öğretim elemanından 26'sının yeterliyim, 34 'ünün kısmen yeterliyim ve $28^{\prime}$ inin yetersizim cevabını verdiği görülmektedir. Öğretim elemanlarının çoğunun maddeyle ilgili kendilerini kısmen yeterli gördüklerini belirtmeleri dikkat çekmektedir.

"8.2. Öğretmen adaylarının farklı kültürlere ve deneyimlere sahip öğrencilerle teknoloji kullanarak iş birliği yapabilecekleri öğretim içerikleri tasarlarım." sorusuna 88 öğretim elemanından 22 'sinin yeterliyim, $29^{\prime}$ unun kısmen yeterliyim ve 37 'sinin yetersizim cevabını verdiği görülmektedir. Bu soru anket maddeleri içerisinde öğretim elemanlarının çoğunluğunun yetersiz olduklarını belirttiği maddeden biri olması bakımından dikkat çekmektedir.

"8.3. Farklı düzeylerde teknolojik bağlantı ağına sahip bölge ve kültürler için öğretmen adaylarının intiyaç duyabilecekleri stratejileri ele alırım." sorusuna 88 öğretim elemanından 26 'sının yeterliyim, 30'unun kısmen yeterliyim ve 32'sinin yetersizim cevabını verdiği görülmektedir. Bu soru da anket maddeleri içerisinde öğretim elemanlarının çoğunluğunun yetersiz olduklarını belirttiği maddelerden olması bakımından dikkat çekmektedir. 
Eğitimde teknolojiyi yasal, etik ve sosyal açıdan sorumlu kullanabilme:

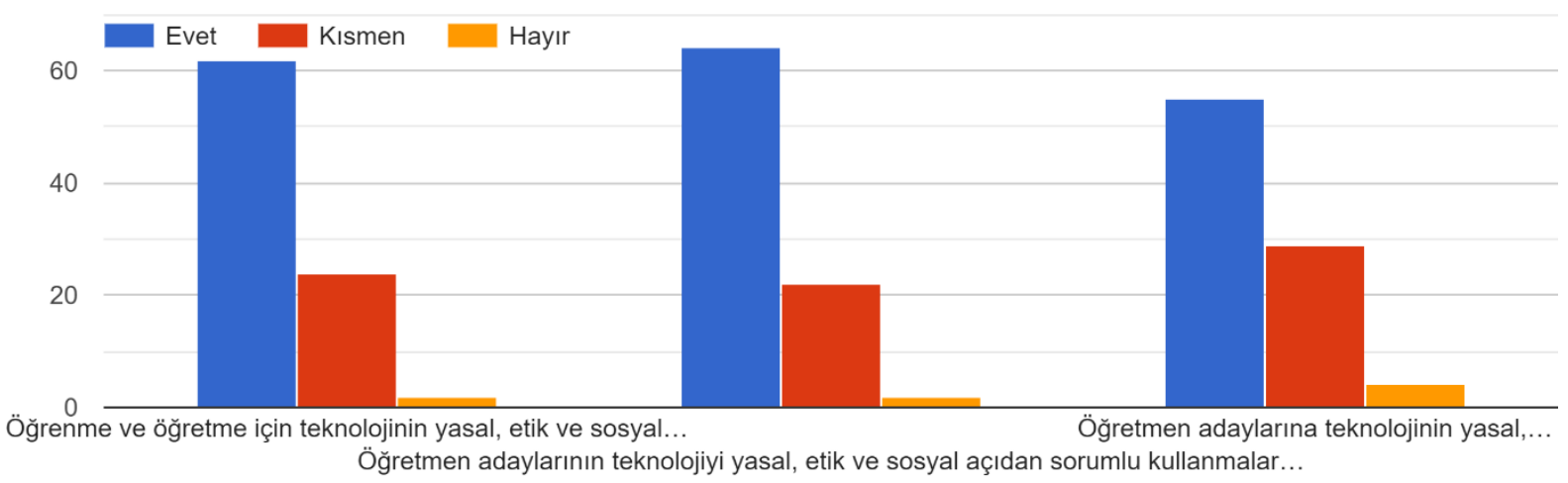

Grafik 12.

Öğretim elemanları "9. Eğitimde teknolojiyi yasal, etik ve sosyal açıdan sorumlu kullanabilme:" başlıklı 3 alt maddeden oluşan sorulara genel olarak kendilerini yeterli gördükleri cevabını vermektedirler:

"9.1. Öğrenme ve öğretme için teknolojinin yasal, etik ve sosyal açıdan sorumlu kullanılmasına model olurum." sorusuna 88 öğretim elemanından 62'sinin yeterliyim, 24'ünün kısmen yeterliyim ve 2 'sinin yetersizim cevabını verdiği görülmektedir.

"9.2. Öğretmen adaylarının teknolojiyi yasal, etik ve sosyal açıdan sorumlu kullanmalarına rehberlik ederim." sorusuna 88 öğretim elemanından 64'ünün yeterliyim, 22'sinin kısmen yeterliyim ve 2 'sinin yetersizim cevabını verdiği görülmektedir.

"9.3. Öğretmen adaylarına teknolojinin yasal, etik ve sosyal açıdan sorumlu kullanılmasına uygun öğretim programları tasarlama fırsatları sağlarım." sorusuna 88 öğretim elemanından 55'inin yeterliyim, 29' unun kısmen yeterliyim ve 4'ünün ise yetersizim cevabını verdiği görülmektedir.

Teknolojinin öğretimle bütünleştirilmesini geliştirmek için sürekli mesleki gelişim ve etkileşim faaliyetlerinde bulunabilme:

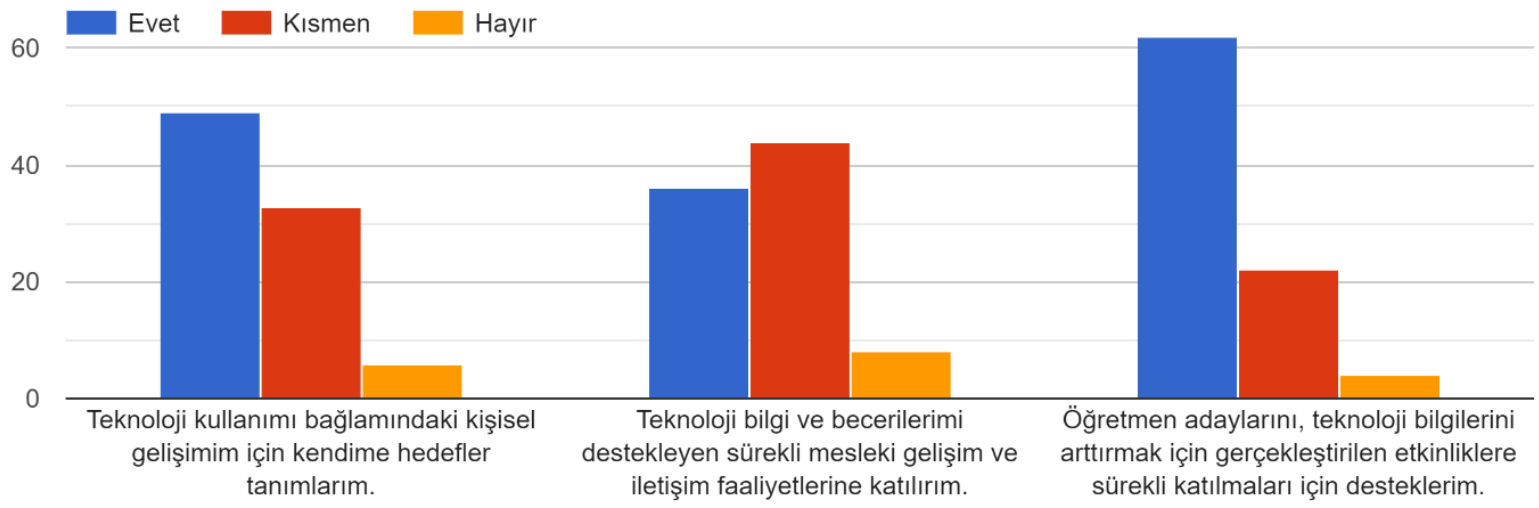

Grafik 13. 
Öğretim elemanları "10. Teknolojinin öğretimle bütünleştirilmesini geliştirmek için sürekli mesleki gelişim ve etkileşim faaliyetlerinde bulunabilme:" başlıklı 3 alt maddeden oluşan sorulara anket genelinden farklı cevaplar vermektedirler:

"10.1. Teknoloji kullanımı bağlamındaki kişisel gelişimim için kendime hedefler tanımlarım." sorusuna 88 öğretim elemanından 49'unun yeterliyim, 33'ünün kısmen yeterliyim ve 6'sının yetersizim cevabını verdiği görülmektedir.

"10.2. Teknoloji bilgi ve becerilerimi destekleyen sürekli mesleki gelişim ve iletişim faaliyetlerine katıııım." sorusuna 88 öğretim elemanından 36'sının yeterliyim, 44'ünün kısmen yeterliyim ve $8^{\prime}$ inin yetersizim cevabını verdiği görülmektedir. Öğretim elemanlarının çoğunun maddeyle ilgili kendilerini kısmen yeterli gördüklerini belirtmeleri dikkat çekmektedir.

"10.3. Öğretmen adaylarını, teknoloji bilgilerini arttırmak için gerçekleştirilen etkinliklere sürekli katılmaları için desteklerim." sorusuna 88 öğretim elemanından 62'sinin yeterliyim, 22'sinin kısmen yeterliyim ve $4^{\prime}$ ünün ise yetersizim cevabını verdiği görülmektedir.

Teknoloji kullanımında liderlik ve savunuculuk yapabilme:

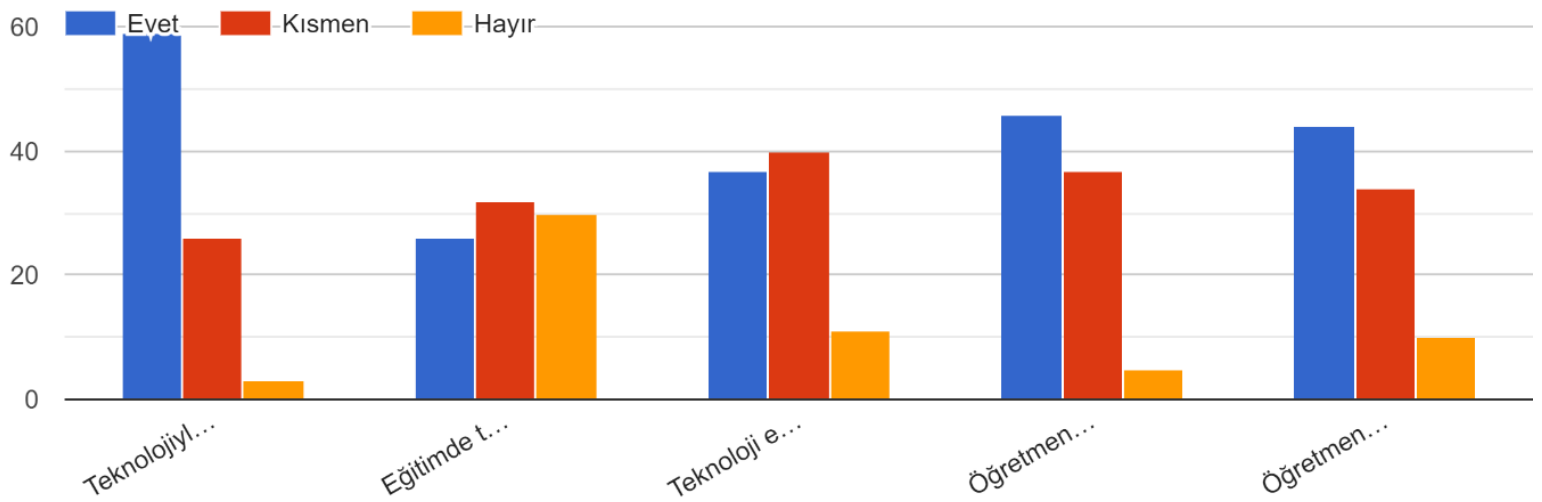

Grafik 14

Öğretim elemanlarının "11. Teknoloji kullanımında liderlik ve savunuculuk yapabilme:" başlıklı 5 alt maddeden oluşan sorulara yeterlilik düzeylerini belirtmek üzere anket genelinden farklı cevaplar verdiği görülmektedir:

"11.1. Teknolojiyle öğrenme ve öğretme vizyonumu öğretmen adaylarıyla paylaşırım." sorusuna 88 öğretim elemanından 59'unun yeterliyim, 26'sının kısmen yeterliyim ve 3'ünün yetersizim cevabını verdiği görülmektedir.

"11.2. Eğitimde teknoloji kullanımını savunan profesyonel kuruluşlarla etkileşim kurarım." sorusuna 88 öğretim elemanından 26'sının yeterliyim, 32'sinin kısmen yeterliyim ve 30'unun yetersizim cevabını verdiği görülmektedir. Öğretim elemanlarının çoğunluğunun kısmen yeterli olduklarını belirttiği maddelerden biri olması bakımından dikkat çekmektedir.

"11.3. Teknoloji entegrasyonuyla ilgili olarak öğretmen adaylarının düşünce ve kararlarını etkilerim." sorusuna 88 öğretim elemanından 37 'sinin yeterliyim, 40'ının kısmen yeterliyim ve $11^{\prime}$ inin yetersizim cevabını verdiği görülmektedir. Bu soru da anket maddeleri içerisinde öğretim elemanlarının çoğunluğunun kısmen yeterli olduklarını belirttiği maddelerden biri olması bakımından dikkat çekmektedir.

"11.4. Öğretmen adaylarının öğrenme ve öğretmeyi geliştirmek için teknolojiyi kullanan savunucular olmalarına yardımcı olurum." sorusuna 88 öğretim elemanından 46 'sının yeterliyim, 37 'sinin kısmen yeterliyim ve 5'inin yetersizim cevabını verdiği görülmektedir. 
"11.5. Öğretmen adaylarının eğitimde yerel, bölgesel ve ulusal teknoloji politikalarını anlamalarını desteklerim." sorusuna 88 öğretim elemanından 44'ünün yeterliyim, 34'ünün kısmen yeterliyim ve 10 'unun yetersizim cevabını verdiği görülmektedir.

Teknoloji sorunlarını çözmek için temel sorun giderme becerilerini uygulayabilme:

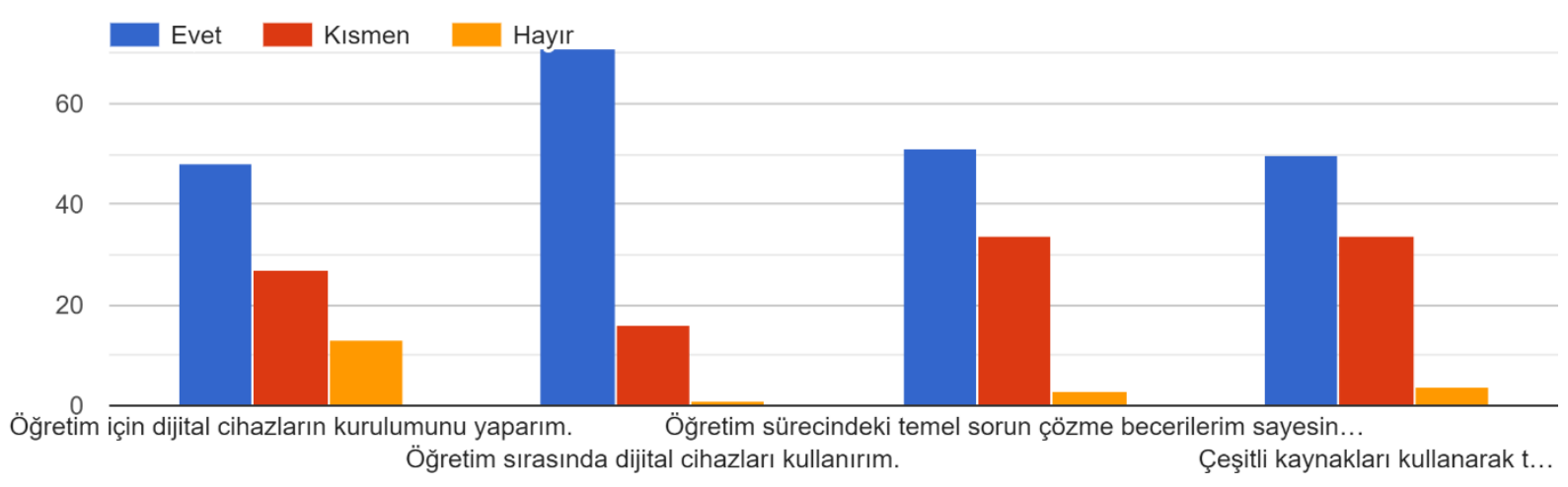

Grafik 15.

Öğretim elemanları "12. Teknoloji sorunlarını çözmek için temel sorun giderme becerilerini uygulayabilme:" başlıklı 4 alt maddeden oluşan sorulara genel olarak kendilerini yeterli gördükleri cevabını vermektedirler:

"12.1. Öğretim için dijital cihazların kurulumunu yaparım." sorusuna 88 öğretim elemanından 48 'inin yeterliyim, 27'sinin kısmen yeterliyim ve 13 'ünün yetersizim cevabını verdiği görülmektedir.

"12.2. Öğretim sırasında dijital cihazları kullanııım." sorusuna 88 öğretim elemanından 71 'inin yeterliyim, 16'sının kısmen yeterliyim ve $1^{\prime}$ inin yetersizim cevabını verdiği görülmektedir.

"12.3. Öğretim sürecindeki temel sorun çözme becerilerim sayesinde öğretmen adaylarına model olurum." sorusuna 88 öğretim elemanından 51'inin yeterliyim, 34'ünün kısmen yeterliyim ve 3'ünün yetersizim cevabını verdiği görülmektedir.

"12.4. Çeşitli kaynakları kullanarak teknolojiyle ilgili sorunlara çözümler bulurum." sorusuna 88 öğretim elemanından 50'sinin yeterliyim, 34'ünün kısmen yeterliyim ve 4'ünün yetersizim cevabını verdiği görülmektedir.

Türkçe eğitimi öğretim elemanlarının 12 başlık altında 41 madde ile kendilerine yöneltilen teknoloji yeterliliklerine dair anket sorularından 33'üne yeterli, 6'sına kısmen yeterli ve 2'sine ise yetersiz oldukları cevabını verdiği görülmektedir.

\section{Tartışma ve Sonuç}

Alanyazın tarandığında alan bilgisi ile pedagoji bilgisine teknoloji bilgisini de dâhil ederek teknolojik pedagojik alan bilgisine yönelik yapılan çalışmaların sayısının geçmişten günümüze, özellikle de salgın başlangıcından günümüze giderek arttığı görülmektedir. Bununla birlikte yapılan çalışmaların büyük çoğunluğunun öğretmen adaylarıyla gerçekleştirildiği görülmektedir. Öğretim elemanlarıyla yapılan çalışmaların sayısının az olduğu dikkat çekmektedir. Kaleli ve Yılmaz (2015), konuyla ilgili bir çalışmalarında inceledikleri 59 çalışmadan sadece 1'inin öğretim elemanlarıyla yürütülmüş olduğunu ifade etmektedirler.

Başıbüyük (2015), öğretim elemanlarının teknolojik pedagojik alan bilgisi öz yeterlilik algılarını çeşitli değişkenlere göre incelediği çalışmasında elde ettiği verilerden hareketle 20 yıldan daha uzun süredir meslekte olan öğretim elemanlarının teknoloji bilgisinde kendilerini yetersiz bulduklarını ifade etmelerine değinmektedir. 
Çakan (2018), İstanbul'daki üniversitelerin eğitim fakültelerinde çalışmakta olan öğretim elemanlarının mevcut Teknolojik Pedagojik Alan Bilgileri (TPAB), TPAB konusunda kendilerine duydukları öz yeterlilik düzeyleri ve öğretimsel stratejilerinin TPAB ve TPAB öz güvenleri ile ilişkisini belirlemeyi amaçladığı çalışmasında; öğretim elemanlarının TPAB ve TPAB öz güven düzeylerinin orta seviyede olduğu, öğrenen-öğreten merkezli pedagojik algıya sahip oldukları, öğretim elemanlarının akademik statüleri yükseldikçe TPAB öz güvenlerinin düştüğü ve 0-5 tecrübe yılına sahip katılımcıların 21 ve daha fazla tecrübe yılına sahip katılımcılara göre daha yüksek TPAB öz güvenine sahip olduğu sonucuna ulaştığını belirtmektedir.

Çam (2018), öğretim elemanlarının teknolojik pedagojik alan bilgilerinin geliştirilmesini amaçladığı çalışmasında elde ettiği bulgulardan hareketle öğretim elemanlarının TBAP uygulamalarını öğrenme-öğretme süreçlerine aktarabilmeleri için teknoloji entegrasyonu uygulamaları konusunda geliştirilmeye ihtiyaç duyulduğu sonucuna ulaştığını ifade etmektedir.

Turan Güntepe ve Keleş (2018), öğrenme-öğretme sürecinde teknoloji entegrasyonunu ele aldıkları çalışmalarında eğitim fakültesi öğretim elemanlarının süreçte bahsi geçen teknolojileri bir araç olarak kullandıkları, teknolojinin dersi zenginleştirdiği ve kolaylaştırdığı, ilgiyi arttırdığı, zaman kazandırdığı ve kalıcı öğrenmeyi desteklediği görüşlerini paylaştıklarını aktarmaktadır. Bununla birlikte öğretim elemanlarının derslerinde teknoloji kullanırken teknik altyapı eksikliği, teknoloji bilgisinin yetersizliği ve teknik aksaklıklardan kaynaklanan sorunlar yaşadıklarını; bu sorunlara paydaşlardan yardım isteme, deneme yanılma metodunu kullanma, farklı teknolojik aletler kullanma veya alternatif yollar deneme gibi çözümler ürettikleri görüşlerini paylaştıklarını belirtmektedir.

Brinkley-Etzkorn (2018), ABD'deki bir üniversitede çevrim içi dersler veren öğretim elemanlarının TPAB gelişimlerini sağlamak için tasarladığı modelin etkisini değerlendirmek üzere gerçekleştirdiği çalışmasında katılımcıların pedagoji ve teknolojinin tam anlamıyla entegrasyonunun oldukça zor olduğunu vurguladıklarını belirtmektedir. Bununla birlikte teknoloji kullanımının öğretim elemanlarının öğretim becerilerini geliştirdiğini ve pedagoji bilgilerini ilerlettiğini tespit ettiğini aktarmaktadır.

Yarar (2019), İngilizce öğretim elemanlarının teknolojik pedagojik alan bilgisi yeterliliklerinin sınıf yönetimine etkisini incelediği çalışmasında öğretim elemanları arasında ortaya çıkan en büyük farkın teknoloji boyutunda olduğunu aktarmaktadır. Ayrıca sınıf yönetiminde teknoloji kullanımıyla ilgili olarak öğretim elemanlarının daha çok çevrim içi-dışı sınavlar, video, görsel araçlar ve dinleme materyalleri konusunda görüş bildirdiklerini; sınıflarında teknoloji kullanırken dersi sunma aşamasında sıklıkla sorunlar yaşadıklarını ve teknolojik yetersizlikler ile teknik sorunlarla karşılaştıklarını söylediklerini belirtmektedir.

Türkçe eğitimi öğretim elemanlarının teknoloji yeterlilik düzeylerinin yine öğretim elemanlarının kendi görüşlerinden hareketle belirlenmeye çalışıldığı bu çalışmada "Öğretmen Eğiticileri Teknoloji Yeterlilikleri Anketi" ile birlikte "Kişisel Bilgi Formu" da kullanılmıştır. Teknoloji yeterliliklerinin sorgulandığı anket maddeleri kadar ilgili formla elde edilen bilgiler de dikkat çekmektedir. Bu sebeple teknoloji yeterliliklerinin sorgulandığı maddelerden önce öğretim elemanlarının ilgili formun teknolojiyle bağlantılı sorularına vermiş olduğu cevapları irdelemekte fayda olacağı düşünülmektedir. 88 öğretim elemanının \%69.3'ünün (61'inin) lisansüstü eğitim dönemlerinde teknolojiyle ilgili ders almadıklarını ifade ettikleri görülmektedir. Bununla birlikte 88 öğretim elemanının \%45.5'inin (40'ının) de meslek yaşamlarında teknolojiyle ilgili herhangi bir çalışmaya katılmadığını belirttiği görülmektedir. Çağın yakalanabilmesi, yükseköğretim kurumlarında günümüz öğrencilerine günümüz ihtiyaçlarını karşılayabilecek yeterliliklerin kazandırılabilmesi, 21. yüzyıl öğrencilerine 21. yüzyıl insanından beklenen 21. yüzyıl becerilerinin edindirilmesi teknolojiden bağımsız düşünülebilir mi sorusunu akıllara getirmektedir. Ayrıca 88 öğretim elemanının ilgili iki soruya vermiş olduğu bu cevaplara rağmen teknoloji yeterliliklerine dönük anket sorularından 33'üne yeterli oldukları cevabını vermiş olmaları da dikkat çekmektedir. Her ne kadar öğretim elemanlarının büyük çoğunluğu lisansüstünde teknolojiyle ilgili ders almadıklarını ve yine öğretim elemanlarııın neredeyse yarıya yakını meslek yaşamlarında teknolojiyle ilgili çalışmalara katılmadıklarını beyan etmiş olsalar da bu durum, teknoloji yeterliliklerini bireysel gayretlerle geliştirmiş olamayacakları anlamına da gelmemektedir. 
Türkçe eğitimi öğretim elemanlarının büyük çoğunluğunun 12 başlık ve 41 maddeden oluşan anketin 33 maddesinde yeterli, 6 'sında kısmen yeterli ve sadece 2 'sinde kendilerini yetersiz kabul ettiklerini belirtmeleri aslında anket genelinde öğretim elemanlarının $\% 80.48^{\prime}$ lik bir teknoloji yeterlilik düzeyinde olduklarını göstermektedir. 6 maddedeki kısmen yeterliyim cevabı da bu orana dâhil edilecek olursa Türkçe eğitimi öğretim elemanlarının anket genelinde \%95.12'lik bir teknoloji yeterlilik düzeyinde olduğu sonucuna ulaşılmaktadır. Bu oranın Türkçe eğitimi öğretim elemanlarının teknoloji yeterlilik düzeylerinin yüksek seviyede olduğunu gösterdiği düşünülmektedir.

\section{Kaynaklar}

Aksu, M. B., Çivitçi, A., ve Duy, B. (2008). Yükseköğretim öğrencilerinin öğretim elemanlarının ders uygulamaları ve sınıf içi davranışlarına ilişkin görüşleri. Inönü Üniversitesi Eğitim Fakültesi Dergisi, 9(16), 17-42.

Başıbüyük, B. (2015). Öğretim elemanlarının teknolojik pedagojik alan bilgisi öz yeterlilik algılarının çeşitli değişkenler açısından incelenmesi (Yayımlanmamış yüksek lisans tezi). Sakarya Üniversitesi Eğitim Bilimleri Enstitüsü, Sakarya.

Büyüköztürk, Ş., Çakmak, E. K., Akgün, Ö. E., Karadeniz, Ş., \& Demirel, F. (2017). Bilimsel araştırma yöntemleri. Ankara: Pegem Yayınları.

Brinkley-Etzkorn, K. E. (2018). Learning to teach online: Measuring the influence of faculty development training on teaching effectiveness through a TPACK lens. The Internet and Higher Education, 38, 28-35.

Çakan, Ş.N. (2021). Öğretim elemanlarının teknolojik pedagojik alan bilgisi yeterlilik düzeylerinin farklı değişkenler açısından incelenmesi (Yayımlanmamış yüksek lisans tezi). İstanbul Aydın Üniversitesi Lisansüstü Eğitim Enstitüsü, İstanbul.

Çakır, H. ve Önal, N. (2015). Eğitim fakültesi öğretim elemanlarının teknolojik pedagojik içerik bilgilerine ilişkin özgüven algıları. Hasan Ali Yücel Eğitim Fakültesi Dergisi, 12-2(24), 117-131.

Çam, Ş. S. (2018) Öğretim elemanlarının teknolojik pedagojik alan bilgilerinin geliştirilmesi için bir mesleki gelişim program önerisi (Yayımlanmamış doktora tezi). Gazi Üniversitesi Eğitim Bilimleri Enstitüsü, Ankara.

Elçi, A. ve Vural, M. (Mayıs, 2017). Öğretim elemanı 4.0: Öğretim elemanının değişsen rolü ve teknoloji ile zenginleştirilmiş öğrenme. Mediterranean International Conference on Social Sciences by UDG Mediterranean Economy, Culture, Architecture and Security, Podgorica.

Foulger, T. S., Graziano, K. J., Schmidt-Crawford, D., \& Slykhuis, D. A. (2017). Teacher educator technology competencies. Journal of Technology and Teacher Education, 25(4), 413-448.

Kabaran, H. (2016). Öğretim elemanlarının teknolojik pedagojik alan becerileri (TPAB) ile öğretme stilleri arasındaki değişkenlerin incelenmesi (Yayımlanmamış yüksek lisans tezi). Muğla Sıtkı Koçman Üniversitesi Eğitim Bilimleri Enstitüsü, Muğla.

Kabaran, H. ve Aykaç, N. (2018). Öğretim elemanlarının teknolojik pedagojik alan bilgilerinin çeşitli değişkenler açısından incelenmesi: Muğla Sıtkı Koçman Üniversitesi örneği. Yükseköğretim Dergisi, 8(3), 322-333.

Keleş, E. ve Turan Güntepe, E. (2018). Eğitim fakültesi öğretim elemanlarının teknolojiyi öğrenme öğretme sürecine entegrasyonu. Sakarya University Journal of Education, 8(3), 142-157.

Odabaşı, F., Fırat, M., İzmirli, S., Çankaya, S. ve Mısırlı, A. (2010). Küreselleşen dünyada akademisyen olmak. Anadolu Üniversitesi Sosyal Bilimler Dergisi, 10(3), 127-142.

Pierson, M. (1999). Technology practice as a function of pedegogical expertise (Yayımlanmamıs doktora tezi). Arizona State University, Arizona.

Turan, Z., Küçük, S. ve Gündoğdu, K. (2013). Öğretmen eğitiminde bilişim teknolojilerinin kullanımı: Mevcut ve beklenen durum. Adnan Menderes Üniversitesi Eğitim Fakültesi Eğitim Bilimleri Dergisi, 4(1), 1-9.

U.S. Department of Education, Office of Educational Technology, (2017). Reimagining the Role of Technology in Education: 2017 National Education Technology Plan Update, Washington, D.C. 
Yarar, G. (2019). Ingilizce öğretim elemanlarının teknolojik pedagojik alan bilgisi yeterliliklerinin sınıf yönetim profilleri açııından incelenmesi (Yayımlanmamış doktora tezi). Gazi Üniversitesi Eğitim Bilimleri Enstitüsü, Ankara.

Yılmaz, G. K. (2015). Türkiye'deki teknolojik pedagojik alan bilgisi çalışmalarının analizi: bir metasentez çalışması. Eğitim ve Bilim, 40(178), 103-122.

\section{Extended Abstract}

\section{Introduction}

In our current era, where technology is developing very fast; it is necessary for individuals, and naturally for society, to make progress by adapting to these developments. New technologies have significantly affected all vital activities by appearing almost every part of life. As in almost every field of life, education is also affected by these changing and developing new technologies. As a natural consequence of the change and development in technology, it is more crucial to include technology in educational environments where individuals having the knowledge, skills and behaviors that can meet the needs of the age will be raised.

Considering that education is one of the most important areas affected by the latest changes and developments in 21st century technology, it is known it is only possible to raise qualified individuals who can keep up with the times only by an effective education and that the indispensable part of an effective education which can create desired behaviors in individuals is education programs.

It is expected that teachers, alongside the students who are called digital natives with 21st century skills who are open to innovations and can adapt to technology as required by this era, should have the knowledge and skills to effectively benefit from information and communication technologies in the learning-teaching process. Teachers, who are practitioners of educational programs in the educational process, should not be digital strangers against digital natives. Since, 21st century teachers are expected to be able to choose suitable technologies for the objectives of their lessons in the learning-teaching processes and use them in their lessons and improve themselves continually.

The significance of technology use for education emerges as an indisputable fact. Teachers need to combine technology with their specialties in order to use technology effectively and efficiently in education. For this reason, educators need to have the qualifications to acquire all kinds of technological knowledge that they can use in their lessons and to reconsider their educational status in the light of technological developments (Yarar, 2019).

Today, lecturers are expected to be guides who can offer Technology-Enriched Learning (FBI) environments to students besides their traditional roles. Lecturers are expected to be able to design, develop and use FBI by making use of different learning theories in the education process. The ability of lecturers to realize what is expected and requested from them initially depends on developing their technological knowledge and having competence in this context.

At the present time, the new competencies that the lecturers should have, beyond transferring the knowledge they have as field experts to the students, are emphasized for the integration of new technologies into education. The competences of lecturers on field, pedagogy and technology knowledge are explained as Technological Pedagogical Content Knowledge (TPACK). For this reason, TPACK emerges as an important qualification that means the ability of lecturers to integrate their current field and pedagogical knowledge with new technology knowledge (Kabaran \& Aykaç, 2018).

According to Pierson (1999), TPAB, which emerged as a result of the addition of technology knowledge in line with today's needs, to the pedagogical knowledge that enables educators to effectively transfer this knowledge to the learner with the field knowledge that educators should have, is expressed as " the ability of educators to use technology and technological tools effectively and efficiently in accordance with the objectives of the course." (Yarar, 2019).

TPACK levels of academics means the qualifications that they have in their specialties, the methods and techniques they prefer in the education-teaching process, their level of use of 
technology and their ability to combine all of them. It is important for higher education institutions to determine the level of technological competence of the lecturers. When the literature has been reviewed, it has been found out that most of the studies on technology competencies has been carried out with teachers, teacher candidates and students and that few studies have been conducted on the technology competences of teaching staff (Kabaran \& Aykaç, 2018; Güntepe \& Keleş, 2018; Çakır \& Önal, 2015). It is considered that this study, which will be one of the first studies among the researches dealing with the technological competencies of Turkish education lecturers, will contribute to the literature and will shed light on new studies to be made in this context.

\section{Method}

This study was carried out with a survey design, which is one of the quantitative research methods. According to Creswell (2017), tendencies, attitudes or opinions in the universe can be described as quantitatively or qualitatively thanks to the studies carried out on a sample selected from a universe with this design. In other words, studies which aim to collect data to determine certain characteristics of a group are called as survey research (Büyüköztürk et al., 2013).

\section{Result and Discussion}

When the literature is reviewed, it has been seen that the number of studies on technological pedagogical content knowledge by including technology knowledge in subject matter knowledge and pedagogical knowledge has increased from past to present, especially from the beginning of the epidemic to the present. However, it has been found that the majority of the studies were carried out with teacher candidates. It is conspicuous that the number of studies conducted with instructors is low. Kaleli and Yılmaz (2015) state that only 1 study was conducted with lecturers out of 59 studies they examined in a research.

Başıüyük (2015), states based on the data he obtained in a study he examined the technological pedagogical content knowledge self-efficacy perceptions of the lecturers according to various variables that the lecturers who have been in the profession for more than 20 years expressed that they found themselves insufficient in technology knowledge.

Based on the findings of his study which aimed to improve the technological pedagogical content knowledge of the lecturers, Çam (2018) states that he has concluded there is a need for improvement in technology integration applications so that the instructors can transfer TPACK applications to the learning-teaching processes.

Brinkley-Etzkorn (2018), who conducted a study to evaluate the effect of the model designed for the lecturers giving online courses at a university in the USA to ensure their TPACK development, has pointed out that the participants in his study emphasized the difficulty of fully integrating pedagogy and technology. In addition, he has stated that the use of technology improves the teaching skills of the lecturers and improves their pedagogical knowledge.

In this study, in which the technology proficiency levels of Turkish education lecturers are tried to be determined based on the lecturers' own views, the "Personal Information Form" and "Teacher Trainers Technology Competence Questionnaire" were used together. The data collected through the relevant form draws attention as well as the questionnaire items in which technology competencies are questioned. For this reason, it is considered that it will be useful to examine the answers given by the lecturers to the technology-related questions of the relevant form before the items in which technology competencies are questioned. It has been seen that 61 of the 88 lecturers (corresponding to $69.3 \%$ ) stated that they did not take technology-related courses during their postgraduate education. However, it has been observed that 40 of 88 lecturers (which corresponds to 45.5\%) stated that they did not participate in any technology-related study in their professional life. It brings to mind the question of whether the situation of catching up with the era, providing today's students with the competencies that can meet today's needs in higher education institutions and providing 21st century students with the 21st century skills expected from the 21st century people can be considered as independent from technology. However, it is remarkable that despite of the answers given by 88 lecturers to the two related questions, they answered that they were sufficient 
for 33 of the survey questions on technology competencies. Although the majority of the lecturers expressed that they did not take technology-related courses in their post-graduate education and almost half of the lecturers stated that they did not participate in technology-related studies in their professional life, this does not mean that they cannot have developed their technological competencies with individual efforts.

The fact that the majority of Turkish education lecturers stated that they considered themselves as sufficient in 33 items, partially sufficient in 6 of them and insufficient in only 2 of the questionnaire consisting of 12 titles and 41 items, in fact, shows that the lecturers are at a technology proficiency level of $80.48 \%$ throughout the questionnaire. If the answer of 6 lecturers, who thought themselves as partially sufficient, is included in this rate, it is concluded that the lecturers have a technology proficiency level of $95.12 \%$. It is thought that this rate is really high in terms of technology proficiency levels of Turkish education lecturers.

\section{Ekler}

Ek-1. Öğretmen Eğiticileri Teknoloji Yeterlilikleri Anketi

1. Öğrenme ve öğretmeyi geliştirmek için içeriğe özgü teknolojiler barındıran öğretim tasarlayabilme:

1.1. Öğrenme ve öğretme için içeriğe özgü teknolojilerden yararlanırım.
Evet ( )
Kısmen ( )
Hayır ( )

1.2. Pedagojik yaklaşım ve uygun teknolojilerle uyumlu içerikler düzenlerim.

Evet ( )

Kısmen ( )

Hayır ( )

1.3. Pedagoji ve içerikle uyumlu örnek yaklaşımlarla öğretim gerçekleştiririm.

Evet ( ) Kısmen ( ) Hayır ( )

2. Öğretmen adaylarını teknolojiyi etkili bir şekilde kullanmaya hazırlayacak pedagojik yaklaşımları eğitimlerine dâhil edebilme:

2.1. Bilgiye erişme, bilgiyi analiz etme, oluşturma ve değerlendirme için teknoloji kullanımına model olurum.

Evet () Kismen ( ) Hayır ( )

2.2. Öğretmen adaylarının, öğrencilerin öğrenmelerini destekleyebilecekleri içeriğe özgü teknoloji olanaklarından yararlanmalarını sağlarım.

Evet ( ) Kısmen ( ) Hayır ( )

2.3. Öğrencilerin öğrenmelerini desteklemek için içeriğe özgü teknolojilerin seçimi ve kullanımı konusunda öğretmen adaylarına yardımcı olurum.
Evet ( )
Kısmen ( )
Hayır ( )

2.4. Öğretmen adaylarına, teknolojiyle öğretim için uygulama fırsatları sağlarım.
Evet ( )
Kısmen ( )
Hayır ( )

3. Öğretmen adaylarının teknolojik alan bilgi, beceri ve tutumlarının gelişimini destekleyebilme:

3.1. Öğretmen adaylarının uygun teknoloji ve pedagojiyle uyumlu içerik oluşturmalarını desteklerim.

Evet ( ) Kismen ( ) Hayır ( )

3.2. Öğretmen adaylarına, öğretimde ve kendi öğrenmelerinde teknoloji kullanımına yönelik tutumlarını yansıtma firsatları sunarım.
Evet ( )
Kısmen ( )
Hayır ( )

3.3. Öğretmen adaylarının öğretimde teknoloji kullanımı konusundaki yeterliliklerini geliştirmelerine olanak sağlarım.
Evet ( )
Kısmen ( )
Hayır ( )

\section{4. Öğrenme ve öğretmeyi geliştirmek için çevrim içi araçları kullanabilme:}

4.1. Çevrim içi araçları kullanarak iletişim kurarım.
Evet ( )
Kısmen ( )
Hayır ( ) 
4.2. Çevrim içi araçları kullanarak iş birliği yaparım.
Evet ( )
Kısmen ( )
Hayır ( )

4.3. Çevrim içi araçları kullanarak öğretim tasarlarım.
Evet ( )
Kısmen ( )
Hayır ( )

4.4. Çevrim içi araçları kullanarak öğretmen adaylarını değerlendiririm.

Evet () Kısmen () Hayır ()

5. Farklı öğrenme ihtiyaçlarının karşılanması için öğretimi çeşitlendiren teknolojileri kullanabilme:

5.1. Farklı öğrencilerin ihtiyaçlarını karşılayabilmek için teknoloji kullanarak öğretim tasarlarım.
Evet ( )
Kısmen ( )
Hayır ( )

5.2. Öğrencilerin bireysel ihtiyaçlarına uygun olarak öğrenmeyi en üst düzeye çıkarmak için kullanılabilecek yardımcı teknolojileri tanıtırım.
Evet ( )
Kısmen ( )
Hayır ( )

5.3. Öğrenme ve öğretmede teknoloji kullanarak öğrenmeyi farklılaştırmak için model olurum.
Evet ( )
Kısmen ( )
Hayır ( )

5.4. Öğretmen adaylarına öğretimi farklılaştırmak için teknoloji kullanarak öğrenme etkinlikleri oluşturma fırsatları sağlarım.
Evet ( )
Kısmen ( )
Hayır ( )

\section{Değerlendirme için uygun teknoloji araçlarını kullanabilme:}

6.1. Öğretmen adaylarının bilgi ve yeterliliklerini değerlendirmek için teknolojiyi kullanırım.
Evet ( )
Kısmen ( )
Hayır ( )

6.2. Çeşitli teknolojik değerlendirme uygulamaları kullanarak öğretmen adaylarına model olurum.
Evet ( )
Kısmen ( )
Hayır ( )

6.3. Öğretmen adaylarına değerlendirmede uygun teknolojiyi kullanmaları için fırsatlar sunarım.
Evet ( )
Kısmen ( )
Hayır ( )

\section{7. Çevrim içi ve/veya harmanlanmış öğrenme ortamlarını öğretmek için etkili stratejiler kullanabilme:}

7.1. Çevrim içi ve harmanlanmışöğrenme yöntem ve stratejileri konusunda öğretmen adaylarına model olurum.
Evet ( )
Kısmen ( )
Hayır ( )

7.2. Öğretmen adaylarına çevrim içi ve/veya harmanlanmış öğrenme ortamlarında öğretim uygulamaları yapma fırsatları sağlarım.
Evet ( )
Kısmen ( )
Hayır ( )

\section{8. Çeşitli bölge ve kültürlerle küresel ölçekte iletişim kurmak için teknolojiyi kullanabilme:}

8.1. Öğretmen adaylarına teknoloji kullanarak diğer kültür ve bölgelerle iletişime geçip küresel bağlantılar kurması için model olurum.
Evet ( )
Kısmen ( )
Hayır ( )

8.2. Öğretmen adaylarının farklı kültürlere ve deneyimlere sahip öğrencilerle teknoloji kullanarak iş birliği yapabilecekleri öğretim içerikleri tasarlarım.
Evet ( )
Kısmen ( )
Hayır ( )

8.3. Farklı düzeylerde teknolojik bağlantı ağına sahip bölge ve kültürler için öğretmen adaylarının ihtiyaç duyabilecekleri stratejileri ele alırım.
Evet ( )
Kısmen ( )
Hayır ( )

\section{Eğitimde teknolojiyi yasal, etik ve sosyal açıdan sorumlu kullanabilme:}


9.1. Öğrenme ve öğretme için teknolojinin yasal, etik ve sosyal açıdan sorumlu kullanılmasına model olurum.

Evet ( ) Kismen ( ) Hayır ( )

9.2. Öğretmen adaylarının teknolojiyi yasal, etik ve sosyal açıdan sorumlu kullanmalarına rehberlik ederim.
Evet ( )
Kısmen ( )
Hayır ( )

9.3. Öğretmen adaylarına teknolojinin yasal, etik ve sosyal açıdan sorumlu kullanılmasına uygun öğretim programları tasarlama fırsatları sağlarım.
Evet ( )
Kismen ( )
Hayır ( )

10. Teknolojinin öğretimle bütünleştirilmesini geliştirmek için sürekli mesleki gelişim ve etkileşim faaliyetlerinde bulunabilme:

10.1. Teknoloji kullanımı bağlamındaki kişisel gelişimim için kendime hedefler tanımlarım.
Evet ( )
Kısmen ( )
Hayır ( )

10.2. Teknoloji bilgi ve becerilerimi destekleyen sürekli mesleki gelişim ve iletişim faaliyetlerine katılırım.
Evet ( )
Kısmen ( )
Hayır ( )

10.3. Öğretmen adaylarını, teknoloji bilgilerini arttırmak için gerçekleştirilen etkinliklere sürekli katılmaları için desteklerim.
Evet ( )
Kısmen ( )
Hayır ( )

\section{Teknoloji kullanımında liderlik ve savunuculuk yapabilme:}

11.1. Teknolojiyle öğrenme ve öğretme vizyonumu öğretmen adaylarıyla paylaşııım.
Evet ( )
Kısmen ( )
Hayır ( )

11.2. Eğitimde teknoloji kullanımını savunan profesyonel kuruluşlarla etkileşim kurarım.
Evet ( )
Kısmen ( )
Hayır ( )

11.3. Teknoloji entegrasyonuyla ilgili olarak öğretmen adaylarının düşünce ve kararlarını etkilerim.
Evet ( )
Kısmen ( )
Hayır ( )

11.4. Öğretmen adaylarının öğrenme ve öğretmeyi geliştirmek için teknolojiyi kullanan savunucular olmalarına yardımcı olurum.
Evet ( )
Kısmen ( )
Hayır ( )

11.5. Öğretmen adaylarının eğitimde yerel, bölgesel ve ulusal teknoloji politikalarını anlamalarını desteklerim.
Evet ( )
Kısmen ( )
Hayır ( )

12. Teknoloji sorunlarını çözmek için temel sorun giderme becerilerini uygulayabilme:

12.1. Öğretim için dijital cihazların kurulumunu yaparım.

Evet () Kismen ( ) Hayır ( )

12.2. Öğretim sırasında dijital cihazları kullanırım.

Evet () Kısmen ( ) Hayır ( )

12.3. Öğretim sürecindeki temel sorun çözme becerilerim sayesinde öğretmen adaylarına model olurum.
Evet ( )
Kısmen ( )
Hayır ( )

12.4. Çeşitli kaynakları kullanarak teknolojiyle ilgili sorunlara çözümler bulurum. 